Polona Vidmar

University of Maribor, Faculty of Arts, Department of Art History

\title{
Cæsari in mis omni hora fidelis servivi: The Portraits of Sigismund Herberstein and Walter Leslie in Diplomatic Robes
}

\author{
Original scientific paper - Izvorni znanstveni rad \\ Received - Primljen 14. 6. 2019. \\ UDK 7.041.5:929Herberstein, Žigmund"15" \\ 7.041.5:929Leslie, Walter"16"
}

DOI 10.31664/ripu.2019.43.06

\begin{abstract}
This paper discusses the portraits of two imperial ambassadors to the Ottoman Porte, Sigismund Baron Herberstein, who met with Sultan Suleiman the Magnificent in 1541, and Walter Count Leslie, who led the Grand Embassy to Sultan Mehmed IV in 1665-1666. The portraits are discussed in the context of their commissions, focusing on the diplomatic robes and the self-representative intentions of the commissioners. Her-

berstein's decision to illustrate his autobiographical works with full body portraits is presented in the context of glorifying poems printed in some prestigious editions of his works, and in the context of the family's portrait galleries. New light is shed on the painted portraits of Walter Leslie based on documents from the family archives, as well as on engraved portraits of the ambassador illustrating the travelogue of his mission.
\end{abstract}

Keywords: Sigismund Herberstein (1486-1566), Walter Leslie (1606-1667), imperial ambassadors, portrait, Donat Hübschmann, Frans van der Steen

The portraits of imperial diplomats to the Ottoman court, dressed in oriental robes, have only recently received the attention of art historians. As Nina Trauth has pointed out, of the 120 ambassadors (approximately) who travelled from Vienna to the Porte from around 1500 until 1740, only Johann Rudolph Schmid Baron Schwarzenhorn, Walter Count Leslie, Wolfgang IV Count Oettingen-Wallerstein and possibly Leslie's companion Johann Joseph Count Herberstein commissioned their portraits in oriental robes; Trauth described the portraits as a political masquerade. ${ }^{1}$ The number of commissioned portraits is unexpectedly low, even if we consider the possibility that some oil paintings may not have been preserved; however, the number is increased by including prints. Friedrich Polleroß provided an extremely thorough discussion of the portraits of diplomats in the graphic medium and categorised the depictions of the Early Modern diplomats into portraits, allegories and historical scenes, which he described as a medium of political communication. ${ }^{2}$ The present paper focuses on the portraits of Sigismund Baron Herberstein (1486-1566), who met with Sultan Suleiman the Magnificent in a military camp near Budim in 1541, ${ }^{3}$ and Walter Count Leslie (1606-1667), who led the Grand Embassy to Sultan Mehmed IV to Constantinople in 1665-1666. These works were selected despite the chronological gap between their missions, as Herberstein's portraits were considered by Friedrich Polleroß to be not only the oldest portraits of the diplomats in their official robes in the Habsburg lands but also some of the most impressive or remarkable, ${ }^{4}$ whereas Leslie's embassy was regarded by Arno Strohmeyer as a good example of an effective media event. ${ }^{5}$ The portraits of the two diplomats are discussed in the context of their commissions, with the focus placed on the diplomatic robes and their representative intentions.

Two portraits of Sigismund Herberstein connected to his mission to Sultan Suleiman are part of a series of six full body portraits in diplomatic robes commissioned by Herberstein at the advanced age of 73; the occasion for the commission was the illustration of his autobiographical works (Fig. 1 and 2). ${ }^{6}$ The woodcuts were made by Donat Hübschmann, a painter, draughtsman and block cutter, who moved from Leipzig to Vienna, probably invited by the printer Raphael Hoffhalter. ${ }^{7}$ In 1559, Hübschmann's portraits of Sigismund Herberstein, a portrait of Emperor Ferdinand I and a depiction of Herberstein's coat of arms enriched Herberstein's collection of printing plates for woodcuts, etchings and copper engravings, which he often used to illustrate his books during the last two decades of his life. The extensive use of illustrations led Walter Leitsch to the conclusion that Herberstein's weaknesses were copper engravings and woodcuts, ${ }^{8}$ and 


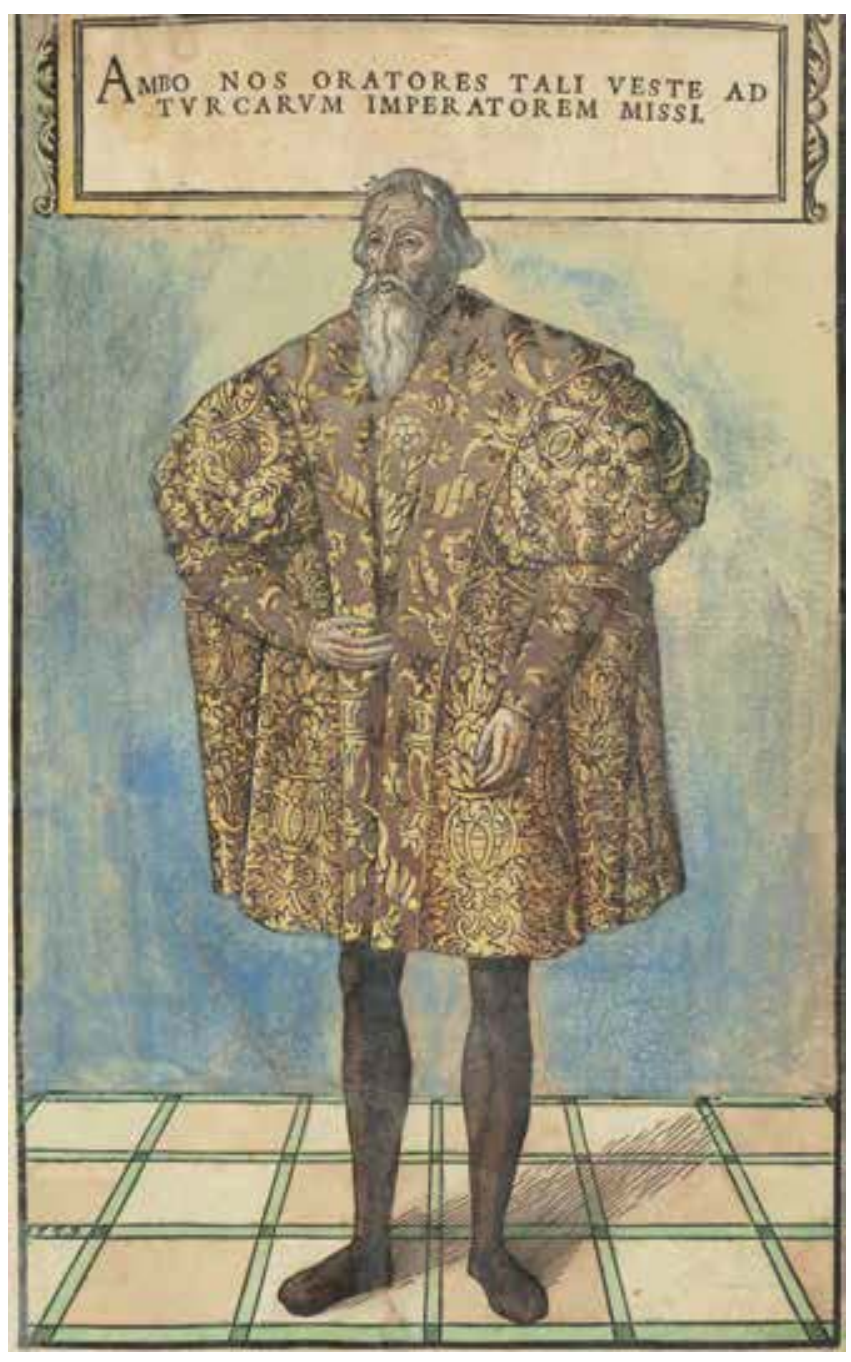

1. Donat Hübschmann, Sigismund Baron Herberstein, 1559, coloured woodcut, in: Gratae posteritati, 1560, Ptuj, Ivan Potrč Library

Donat Hübschmann, Barun Žigmund Herberstein, 1559., kolorirani drvorez, u: Gratae posteritati, 1560., Ptuj, Knjižnica Ivana Potrča

Friedrich Polleroß pointed out that the long-term significance of these illustrations is based on their scientific and ethnographic character. ${ }^{9}$ This is true of the illustrations of Herberstein's most important work, Notes on Muscovite Affairs, but I would like to point out that the message of the six Hübschmann portraits of Herberstein, in which the focus is placed on diplomatic robes, is primarily representative; they were intended to demonstrate the important deeds of Sigismund Herberstein in the service of the imperial house. This hypothesis is based on the verses in Paul Fabritius' glorifying poem printed in the 1560 Vienna edition of the autobiographical work Gratae posteritati, stating that the 'painted' robe Herberstein received from the Grand Duke of Moscow was proof of Herberstein's youthful labours: "Haec quoq: quam picta gestas in imagine vestem / Acta iuuentutis plena laboris habet" ${ }^{10}$

Most important for the illustrations of Herberstein's Notes on Muscovite Affairs was his collaboration with Augustin Hirschvogel prior to the first publication of the book in $\mathrm{Vi}$ enna in $1549 .{ }^{11}$ In the 1540 s Herberstein commissioned two

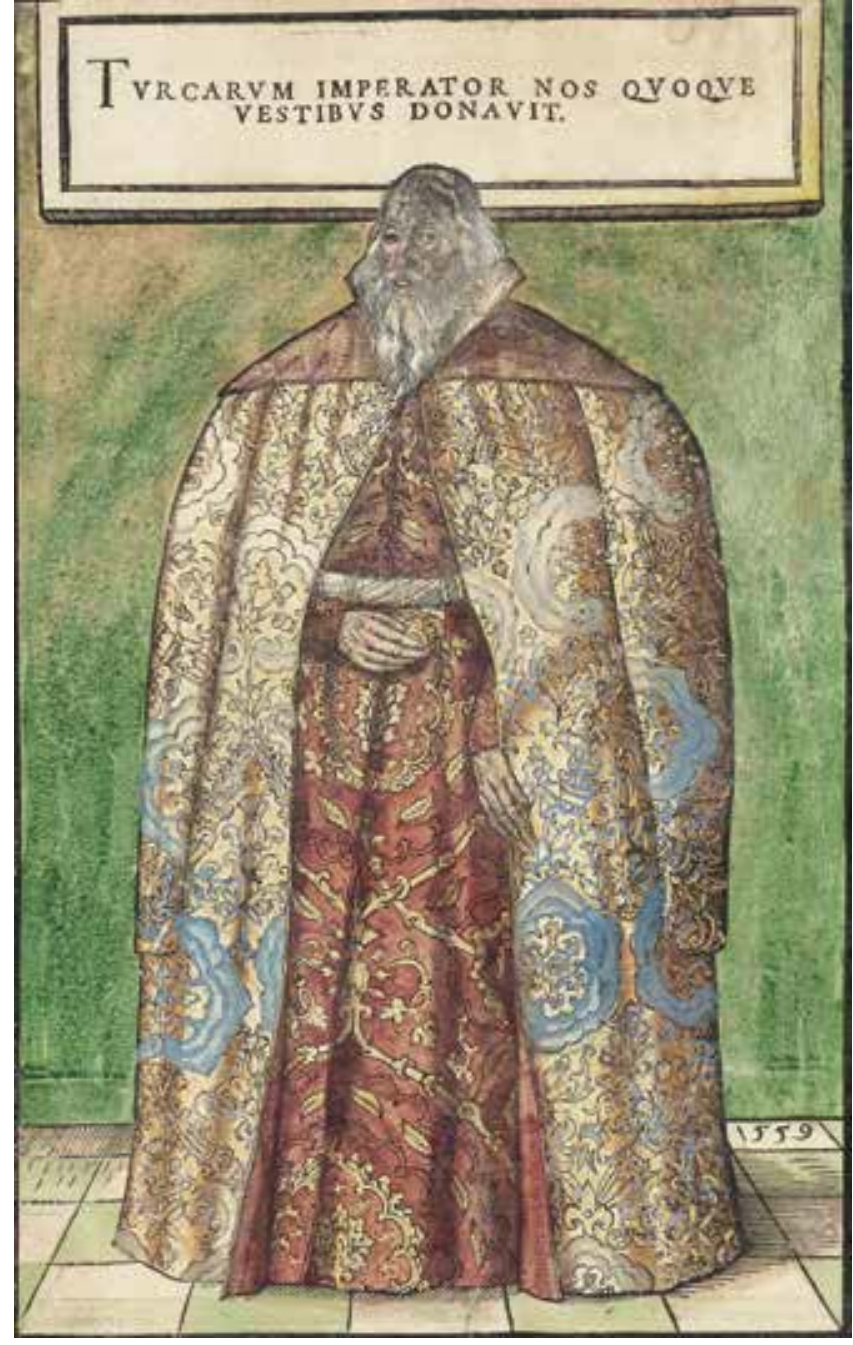

2. Donat Hübschmann, Sigismund Baron Herberstein, 1559, coloured woodcut, in: Gratae posteritati, 1560, Ptuj, Ivan Potrč Library

Donat Hübschmann, Barun Žigmund Herberstein, 1559., kolorirani drvorez, u: Gratae posteritati, 1560., Ptuj, Knjižnica Ivana Potrča

maps of Russia from Hirschvogel, as well as two portraits, a coat of arms, the modes of transport he used, the portraits of the seven European monarchs that were sending Herberstein on diplomatic missions and those that the diplomat was visiting, as well as the portraits of the Grand Duke of Moscow Vasili III Ivanovich and Sultan Suleiman. ${ }^{12}$ In 1547, Hirschvogel made an etching entitled Map of Eastern Europe, with smaller versions of the depictions of monarchs, modes of transport and a Herberstein portrait (Fig. 3). ${ }^{13}$ The Latin edition of the Notes on Muscovite Affairs, printed by Johannes Oporinus in Basel in 1556, was the first which illustrated the Aurochs and the European Bison, presumably woodcut copies by Hans Lautensack (c. 1520-1563/66) after Hirschvogel's etchings, ${ }^{14}$ whereas woodcuts depicting Russian horsemen and Russian saddles and arms in the same Basel edition were probably copied from the lost engravings for the Italian edition, printed in Venice in $1550 .{ }^{15}$ The intended documentary character of the illustrations mentioned is most obvious in two series of etchings depicting seven European monarchs. Hirschvogel made the first series in 1546 and signed all of 


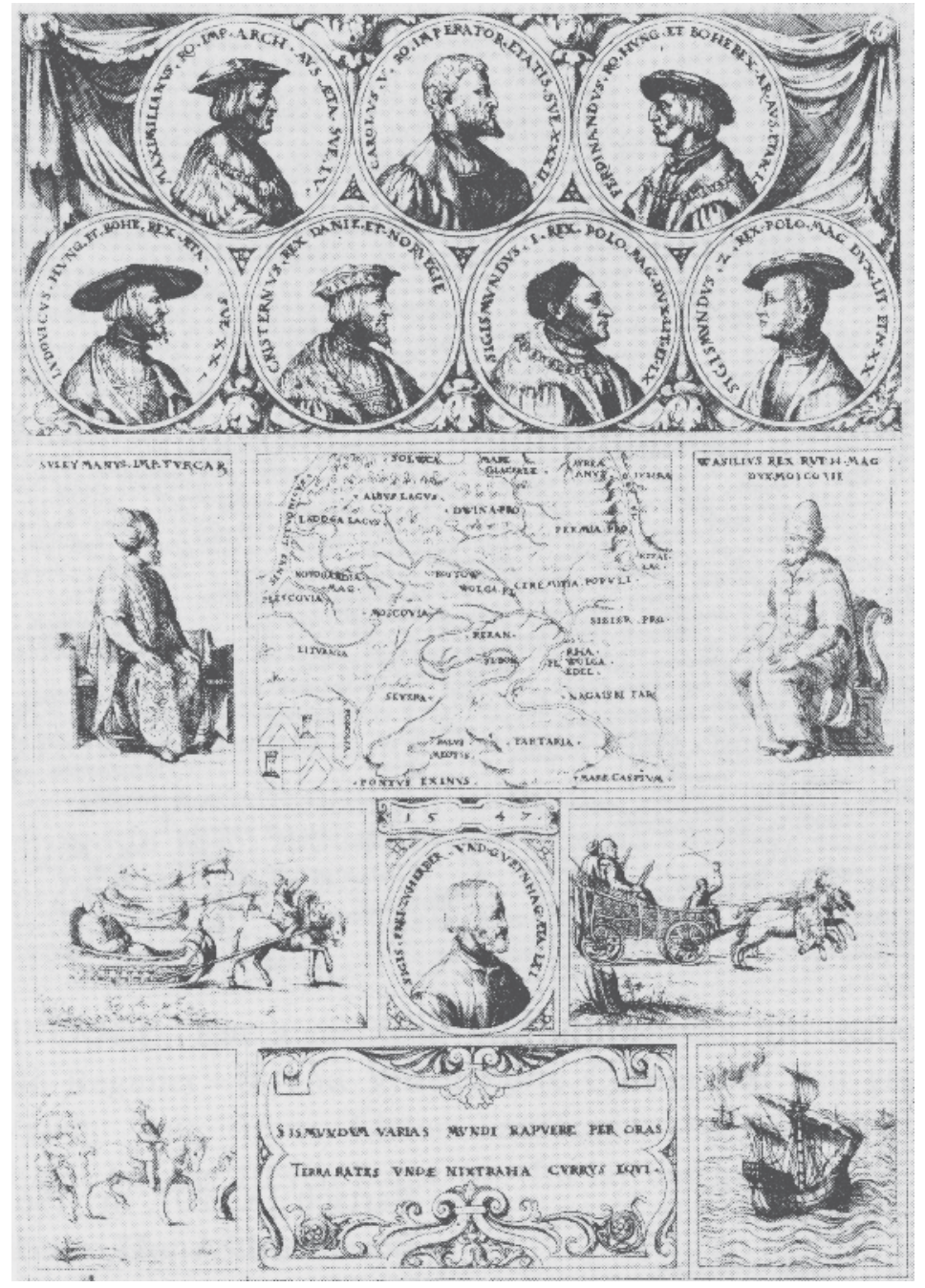

3. Augustin Hirschvogel, Map of Eastern Europe, 1547 Augustin Hirschvogel, zemljovid istočne Europe, 1547.

the portraits with his monogram. ${ }^{16}$ However, Herberstein appears to have been dissatisfied with these depictions, probably because of the somewhat imaginative or eccentric appearance of the monarchs. ${ }^{17}$ Two years later, Hirschvogel produced another seven etchings, this time in traditional medallion form reminiscent of portrait medals (Fig. 4). ${ }^{18}$ The second series came closer to Herberstein's documentary expectations, illustrating several editions of Herberstein's books either in their original form or in woodcut copies. ${ }^{19}$

The representative full body portraits of Sigismund Herberstein by Donat Hübschmann were intended to illustrate Herberstein's autobiographical works, written and partially printed in the last decades of his life. Two autobiographical volumes which remained in manuscript were then edited and published in the $19^{\text {th }}$ century by Theodor von Karajan..$^{20}$ From the autobiographical works printed in Herberstein's lifetime, Karl Enenkel took only five printed autobiographies in German and Latin into consideration, ${ }^{21}$ although the German version was printed with at least four different titles and in at least six editions from 1558 till 1562 by the

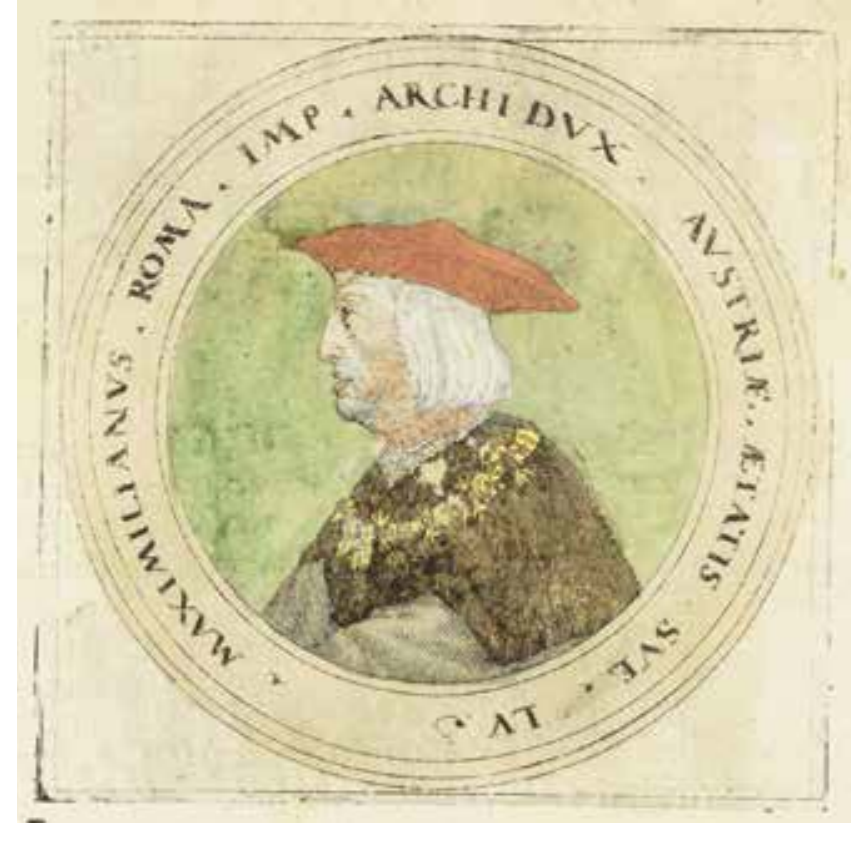

4. Augustin Hirschvogel, Emperor Maximilian I, 1548, coloured engraving, in: Gratae posteritati, 1560, Ptuj, Ivan Potrč Library

Augustin Hirschvogel, Car Maksimilijan I., 1548., kolorirani bakropis, u: Gratae posteritati, 1560., Ptuj, Knjižnica Ivana Potrča

Viennese printers Raphael Hoffhalter and Michael Zimmermann, while the Latin version was printed in 1558 and 1560 by Raphael Hoffhalter under the title Gratae posteritati, and again in 1560 by the same printer, but entitled Picturae variae. Some editions were illustrated, but the illustrations in various editions differ and the placement of illustrations tends to differ within the copies of one edition. To avoid misunderstandings, for this paper I have used only three printed copies, selected because they contain six full body portraits of Herberstein, with slightly varying inscriptions: a copy of the German edition, printed in 1559 by Hoffhalter and entitled Sigmund Freyherr zu Herberstain, which is preserved in the family archive of the Dietrichstein family in the Moravian Land Archives in Brno, ${ }^{22}$ a copy of the Latin edition, printed in 1560 by Hoffhalter, entitled Gratae posteritati and kept in the town library in Ptuj, ${ }^{23}$ and a copy of the Latin edition printed by Hoffhalter in 1560, entitled Picturae variae and kept in the Austrian National Library. ${ }^{24}$

According to the address in the German editions, the autobiographical works were intended for Herberstein's family members, especially those who will carry on his name (“...den Gegenwurtigen und nachkomendn Freyherrn zu herberstain..."), ${ }^{25}$ i.e. his nephews and grandnephews, as he had no offspring. In his self-promoting works, he offered the male members of the Herberstein family examples and guidelines in the hope that they would continue or even surpass his political-diplomatic achievements. ${ }^{26}$ In order to achieve this goal, he almost entirely ignored his early years in the text, placing the focus on his military and political-diplomatic career. He also very carefully selected the illustrations, which placed him in close physical proximity to the most important leaders of his era. ${ }^{27}$ This is most obvious in the Ptuj copy of Gratae posteritaty, in which six 


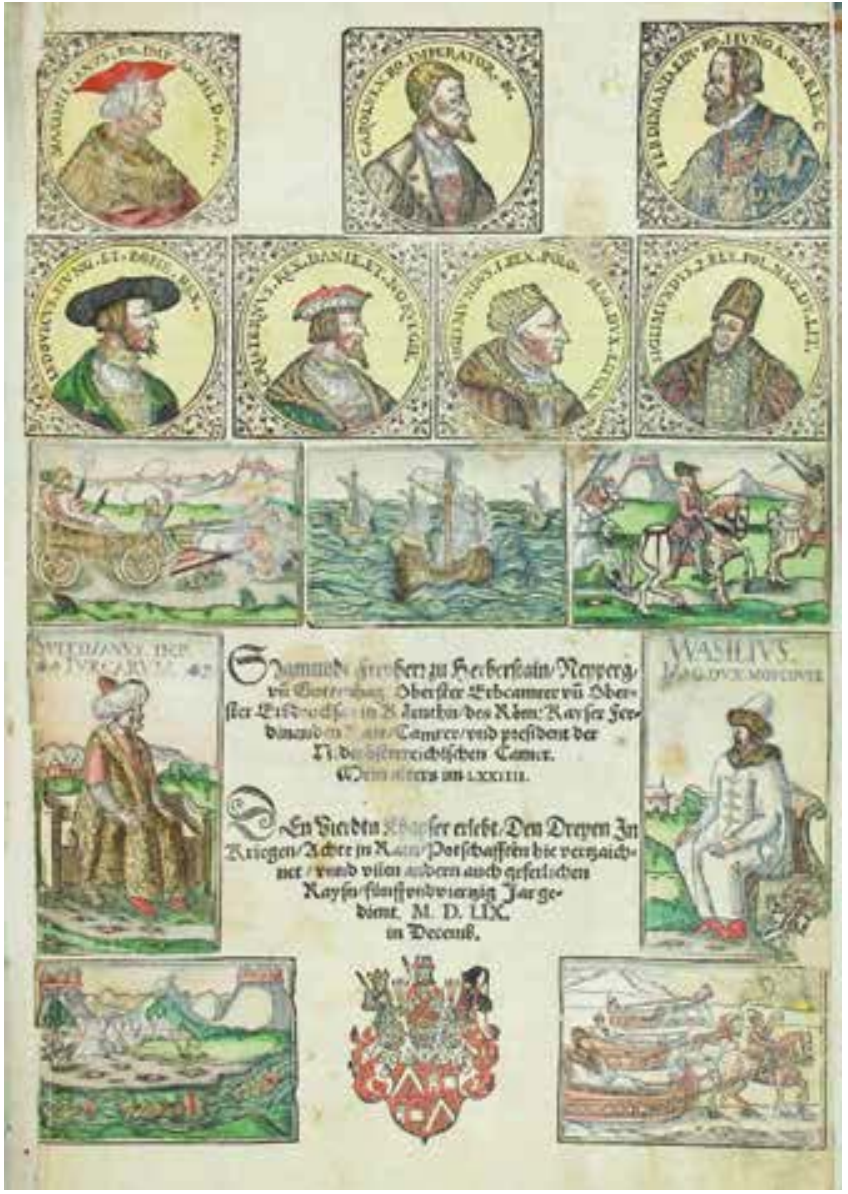

5. Unknown artist, Titlepage, coloured woodcut in Sigmund Freyherr zu Herberstain, 1559, Brno, Moravian Land Archives

Neznani umjetnik, Naslovnica, kolorirani drvorez, Sigmund Freyherr zu Herberstain, 1559., Arhiv Moravske, Brno

full body portraits of Herberstein in court and diplomatic robes, mostly received as gifts from the monarchs he visited, are printed alongside seven portraits of the European monarchs, the Grand Duke of Moscow Vasili III Ivanovich and Sultan Suleiman. Regarding this 1560 Vienna edition of Gratae posteritati, the choice of full body portraits and their size (approximately $275 \times 170 \mathrm{~mm}$ ) give the most likely unintended impression that the diplomat was more important than the monarchs portrayed in Hirschvogel's portrait etchings $(116 \times 116 \mathrm{~mm})$. In the other examined copies, i.e. Picturae variae in the Vienna National Library and Sigmund Freyherr zu Herberstain in the Moravian Land Archives, the portraits of European monarchs, the Grand Duke and the Sultan were not included as separate etchings, but printed in smaller woodcut versions on one page, as a variation on Hirschvogel's etching of 1547 (Fig. 5).

The innovative decision to use full body portraits accentuating the robes is remarkable for a number of reasons. Herberstein decided not to include illustrations representing his education and military career in his autobiographical works, although he was in possession of four woodcut plates on this theme in 1557 at the latest, when they were printed in the 1557 Vienna edition of Notes on Muscovite Affairs. ${ }^{28}$ They depict Herber- stein graduating, Herberstein in arms carrying a banner, Herberstein with a Styrian horseman in the campaign against the Venetians and Herberstein knighted by Maximilian I. ${ }^{29}$

Regarding the already existing depictions of imperial missions to the Ottoman court, Herberstein could have chosen the representations of historical events. Before his journey in 1541, he was probably acquainted with the travel journal of the diplomatic mission of Joseph Lamberg and Nicolaus Jurišić to Sultan Suleiman in 1530, which was written by the official Latin translator of the mission Benedikt Kuripečič. ${ }^{30}$ The 1531 edition of the travel journal contains an illustration of the diplomats Lamberg and Jurišić's audience with the sultan (printed twice) and a similarly constructed reception by a pasha. In both depictions the imperial diplomats are kneeling subordinately in front of the enemy's monarch and dignitary, in obvious contrast to Herberstein's representative intentions.

Only two years before Herberstein's full body portraits were produced, Melchior Lorck (Lorch) portrayed three members of the then embassy in Constantinople. ${ }^{31}$ Antun Vrančić, Ferenc Zay and Ogier Ghiselin de Busbecq, who spent four years in Constantinople (1553-1557), are portrayed dressed in court robes in bust form and are characterized as imperial diplomats only by inscriptions and emblems. Herberstein could have been acquainted with these portraits, but he deliberately chose the more prestigious full body portrait format. As he intended to represent his deeds to his 'loving descendants' only full body portraits were appropriate to display the ceremonial robes he wished to stress entirely. This choice is also echoed in Herberstein's choice of the prestigious folio format for some editions of his autobiographical works. ${ }^{32}$

Herberstein might also have been acquainted with publications in which a full body portrait of the author had been included, as for instance Leonhard Fuchs on the back of the title page of his Historia stirpium, printed in Basel in 1542 (Fig. 6) ${ }^{33}$ In contrast to Herberstein, whose rank of diplomat is recognizable only by the inscriptions, the botanist Fuchs holds a flower in his hand. In the woodcut by Veit Rudolph Specklin after Albrecht Meyer, the botanist is placed against a neutral background, whereas his facial features and the patterns of his short mantle have been depicted with masterfully delicate and precise lines similar to Hübschmann's portraits of Herberstein.

The choice of full body portraits might also have been influenced by the series of painted portraits of Herberstein, possibly adorning his home in Vienna. ${ }^{34}$ They have not been preserved, but their existence can be assumed from the mentions of 'paintings' in the glorifying poems and epigrams written by various poets and included in the 1560 Vienna edition of Gratae posteritati. ${ }^{35}$ A glorifying poem by Paul Fabricius was inspired by the depiction of the robe that Herberstein received as a gift from the Grand Duke of Moscow in 1516: "Illustri ac Generoso Domino D. Sigismvndo (...) ac de pictura illa compellat quæ eum ex Moscouiæ Legatione redeuntem sic vestitum exprimit." ${ }^{36}$ As already stated, in Fabritius' words, the robe in the painted picture was proof of Herberstein's youthful labours. ${ }^{37}$ Fabritius also made reference to a painted picture in his later verses: "Inde reuersuro Dux Moscus munere vestem / Donat vt hæc illam picta tabella refert." 38 Although Fabritius' terminology 


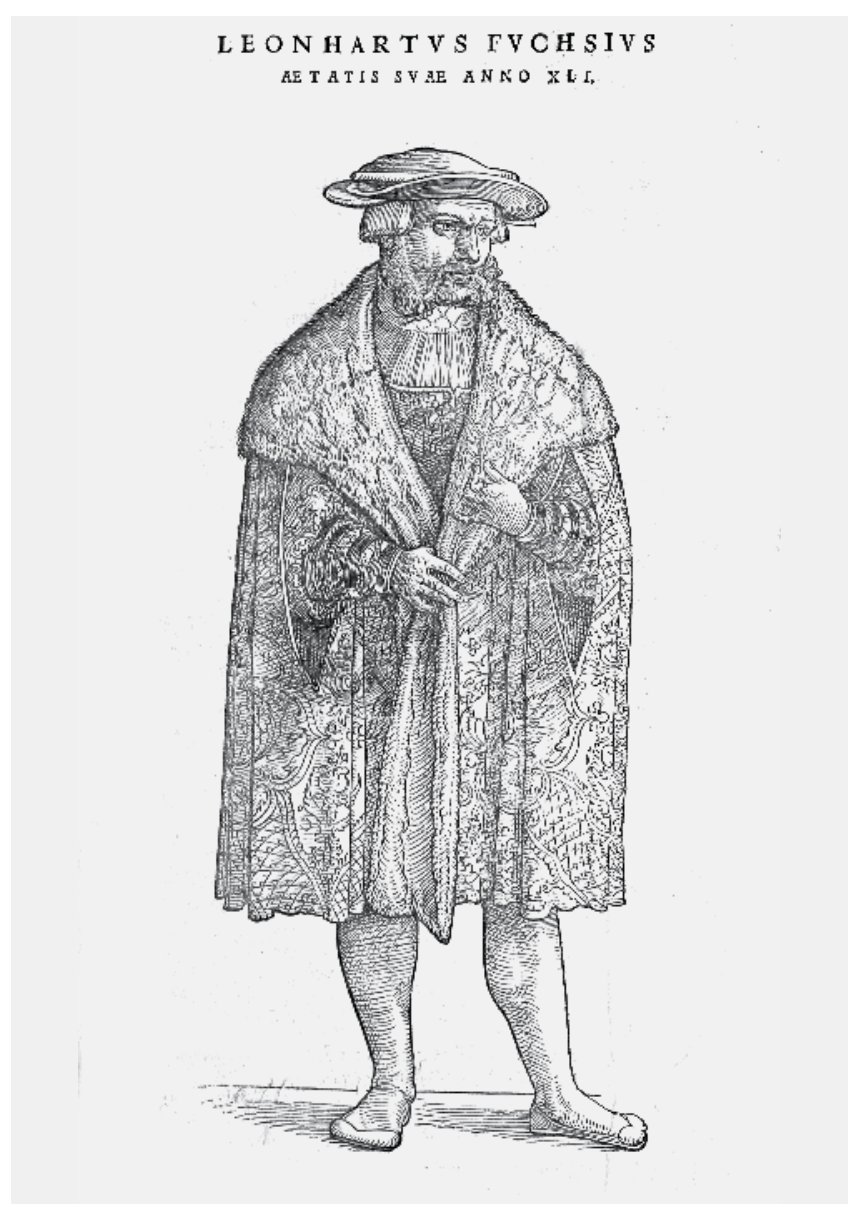

6. Veit Rudolph Specklin after Albrecht Meyer, Leonhard Fuchs, woodcut, in: Historia Stirpium, 1542

Veit Rudolph Specklin prema Albrechtu Meyeru, Leonhard Fuchs, drvorez, $u$ : Historia Stirpium, 1542.

seems to refer to a panel painting, is it also possible that Herberstein presented him with a coloured version of the Hübschmann woodcut. In other glorifying poems there are numerous references to Herberstein's robes, but it is not clear if the poets, Sigismund Torda and Johann Rosinus, authors of Ad Imagines habituum, quibus diuersis in legationibus summorum Principum muneratione est honoratus had seen them depicted in woodcuts or in paintings. ${ }^{39}$ Torda referred to them only as simulacra, without references to the material or technique: "Vim tamen ingenij nequeunt simulachra referre / Ista, nec oeternis acta sacranda notis." ${ }^{40}$ The use of poetic metaphors and inaccurate terminology means that we cannot be absolutely certain that the poets were referring to the woodcuts or paintings. Regarding the Donat Hübschmann woodcuts, it seems that he depicted the diplomat and his diplomatic robes through personal observation, as he demonstrated the utmost precision in the tailoring and patterns of these valuable garments. In some preserved copies of Herberstein's autobiographical works, the illustrations are coloured. I would like to suggest that the copies were coloured upon Herberstein's request, most probably because they were intended for someone highly esteemed by the author, possibly the emperor and members of his extended family, like the copy of Gratae posteritati in
Ptuj. ${ }^{41}$ It is also possible that some copies were coloured by Donat Hübschmann or at least all of them by the same artist, using either the existing garments or the presumed paintings as the visual source. One of the arguments supporting this claim is the use of the same colours in different copies, for instance in small details such as the light blue for the collar on the portrait of Herberstein in the garments in which he travelled to Poland and Moscow in $1517 .{ }^{42}$ In the Ptuj copy, some details of the precious robes were gilded.

Furthermore, the glorifying poems give rise to another question: whether the unpreserved painted portraits could have been part of a Herberstein portrait gallery. On the basis of the poem on the aurochs and the bison by Caspar Pecius, John Nevinson surmised that Herberstein had placed stuffed specimens of these two rare animals in front of the family portraits, ${ }^{43}$ i.e. Nevinson assumed the existence of a Herberstein portrait gallery, probably located in his Vienna house. The verses Nevinson referred to are rather ambiguous and interpreted highly poetically in the recent Slovenian translation by Matej Hriberšek, i.e. that Herberstein placed the furs of these animals in front of his family fireplace: "(...) duorum / Exuuias patrios collocat ante lares." ${ }^{44}$ Although the metaphor 'patrios ante lares' cannot prove unequivocally the existence of a Herberstein portrait gallery, it can be said that around 1560 , a series of family portraits would not have been an impossibility in the residence of a central European nobleman. As Ingrid Halászová pointed out, the painted portraits in the aristocratic residences of Austria and Bohemia that emerged in the 1520 s and 1530s were regarded as the most appropriate method of personal and aristocratic representation. ${ }^{45}$ The same author characterised the era between 1530 and 1560 as the phase of proto-galleries, in which the large-format (half- and full-body) portraits reflected high social standing and were commissioned by itinerant and well-educated noblemen, who could have become acquainted with this phenomenon through their Europe-wide travels and visits to the imperial and archducal residences. ${ }^{46}$ Regarding the full body portraits, the central European noblemen followed the model of court portraits painted by Jakob Seisenegger in the reign of Ferdinand $I{ }^{47}$ Following from this, we can say that the settings of Herberstein's portraits are comparable with the early Seisenegger portrait of Adam I of Hradec (German: Neuhaus), painted in 1529 and preserved in Telč Castle. ${ }^{48}$ Like Herberstein, Adam of Hradec stands self-confidently in an almost empty room. The later obligatory requisites of representative portraits, such as columns, curtains, tables with rank and status defining objects etc., are absent in this portrayal; his high court position is shown only by his precious garments, a sword and a chain. Within a matter of decades, the possession of a small number of individual portraits could have grown into a larger series, eventually forming portrait galleries, ${ }^{49}$ but probably not earlier than the 1570 s and $1580 s .{ }^{50}$ If "lares" in Pecius' poem really does refer to family portraits, Sigismund Herberstein possessed one of the earliest such portrait series in Central Europe, probably consisting of portraits of himself, as well as of his close relatives, wife, parents and possibly siblings.

The presumed possession and commission of a family portrait gallery is consistent with Herberstein's extensive 
genealogical research. Most of it remained in manuscript form and was edited and published only in the $19^{\text {th }}$ century by Josef von Zahn, ${ }^{51}$ but Herberstein included his genealogical research in some German editions of his autobiography. ${ }^{52}$

Herberstein's selection of six diplomatic robes to be depicted in woodcuts was probably not based only on their material value but also on the importance Herberstein ascribed to the particular missions. In the editions of his autobiographical works, the upper sections of the frames were completed with a variety of inscriptions, each one containing different information; only the 1560 edition of Gratae posteritati does not mention his name or the date of the mission. As all the other woodcuts contain these data, it may be assumed that they were not intended to be printed only in his books but also as independent prints. The first woodcut referring to the mission to the sultan depicts Herberstein in a short gown which he wore, and similar to the one worn by Nicolaus of Salm, in 1541. The gown was a court dress also worn by Herberstein when he acted as a "Hofmeister" at the royal wedding in $1543 .{ }^{53}$ As in other woodcuts, the inscriptions in various editions contain variable information ("Ambo nos oratores tali veste ad Tvrcarvm imperatorem missi." ${ }^{54}$ / "Ferdinandi imp: tvnc regis Rom: orator ad Solemanvm Tvrcarvm imperat: M. D. XLI. Sigismvndvs liber baro in Herberstain \&c." ${ }^{5}$ / "Khayser Ferdinandts noch derzeit Ro̊mischen Khünigs Orat: zu Suleiman dem Türckhischen Khay: 1541. Sigmundt freyherr zu Herberstain ec. Gedruckt 1559. Seines Alters im lxxiiij." ${ }^{56}$ ) This is also true for the inscriptions on the woodcut that depicts Herberstein in the robe presented by the sultan ("Tvrcarvm imperator nos qvoqve vestibus donavit." 57 / "Ferdinandi Rom: regis orator a Svleimano Tvrcarvm imperatore tali veste donatvs. Sigismvndvs liber baro in Herberstain. M. D. XLI."58 / "Sigmundt Freyherr zu Herberstain. Gesanter zu dem Türckhischen Khayser von dem also verehrt. M. D. Xlj." ${ }^{59}$ ) In the official report to King Ferdinand, Herberstein and Salm mentioned that the silk caftans presented by Suleiman for the farewell audience were of poor quality. ${ }^{60}$ The veracity of this mention in a diplomatic report is questionable considering the hostile relations between the two monarchs. There is no sign that the caftan was of poor quality in the woodcut and it is depicted with such accuracy that Jennifer Wearden has established that it was most likely tailored of silk velvet woven in Italy ${ }^{61}$

When two of Herberstein's 'loving descendants', whose identities have yet to be determined, but presumably both living in the $18^{\text {th }}$ century, selected the model for the portraits of Sigismund Herberstein intended for the family portrait galleries in Herberstein and Hrastovec castles and now preserved in Herberstein and Ptuj castles, both of them selected the depiction of Sigismund in the Turkish caftan. The unknown painters used coloured woodcuts as models but copied the details with a differing degree of accuracy. On the portrait in Herberstein Castle, Sigismund's figure occupies the whole painted surface. The painter added the Herberstein coat of arms in the lower right corner as well as a window in the upper corner, using its shelf as a pedestal for a turban. The patterns of silk velvet only approximately follow the woodcut, whereas in the Ptuj portrait, the painter copied every detail (Fig. 7). He added a column and a table



7. Unknown artist, Sigismund Baron Herberstein, Regional Museum Ptuj-Ormož

Neznani umjetnik, Barun Žigmund Herberstein, Regionalni Muzej Ptuj-Ormož

following the conventions of representative portraiture and depicted a turban and a sealed letter, defining Herberstein as a diplomat. The selection of the portrait in the Ottoman robes as a model for oil paintings was probably based on its visual appeal and the enduring importance of HabsburgOttoman relations in the Early Modern nobility culture, although Herberstein viewed the mission to the sultan as one of the highlights of his career. ${ }^{62}$ The selection of the model neglected the fact that the fame of Sigismund Herberstein was founded on his embassies to Russia and on his Notes on Muscovite Affairs and not on his mission to the sultan. Since the portraits were probably not painted pre- $18^{\text {th }}$ century, their commissioner also neglected the fact that the obligatory wearing of an Ottoman robe at the audience with a sultan, as practised until the early $18^{\text {th }}$ century, was perceived as an act of humiliation by the Habsburg diplomats, also in the constant dispute about rank with the French diplomats. ${ }^{63}$ According to Andreas Lazarus Imhoff, the foreign diplomats had been obliged to wear a caftan for security reasons from 1390 to prevent assassination attempts on the sultan. ${ }^{64} \mathrm{Im}$ hoff explicitly stated, however, that the French ambassador was the only diplomat who was allowed to appear in French 
garments at the audience as early as 1700 , whereas all others had to wear Ottoman robes. ${ }^{65}$ He contradicts himself on the next page, reporting that ambassador Ferriol took off his caftan after the audience had been refused to him because of his demand to carry a sword. ${ }^{66}$ According to the painting of Charles de Ferriol's 1699 audience by Jean-Baptiste Vanmour, the privileged French ambassador was allowed to wear an open caftan over his court dress. ${ }^{67}$ When in 1744 , Wenzel Samuel Theodor Schmidt used a print after Vanmour's painting to depict the audience of the Habsburg diplomat Joachim Sinzendorf, ${ }^{68}$ resident in Constantinople between 1577 and 1581, he anachronistically painted Sinzendorf in Western European garments and an open caftan. In 1733, Julius Bernhard von Rohr wrote in his Ceremonielwissenschaft that, previously, diplomats had had to wear Ottoman caftans when they were received by the sultan, indicating that the wearing of Ottoman robes was a sign of subordination abandoned only after the successful advances of the Habsburg army on the Balkans. ${ }^{69}$ The commissioners of Herberstein's painted portraits were probably not acquainted with such particulars of diplomatic ceremonial culture when they selected the woodcut portrait of Herberstein in a Turkish caftan as a model to complement the family portrait galleries. The main occasion for such a commission was, as John Burbury, a member of Walter Leslie's embassy to Constantinople, wrote in 1671: "Pictures, which relate to a Family, are usualy exposed in Galleries, that the Heir by looking on them, may not only see the Features, but read too the Vertues and generous Exploits of his truly Noble Ancestors."70

In contrast to Sigismund Herberstein, for whom the mission to Suleiman was one of 69 diplomatic journeys to different courts, ${ }^{71}$ Walter Leslie had less diplomatic experience, being sent to the Cardinal-Infante in Flanders in 1639, to Pope Innocent $\times$ in $1645,{ }^{72}$ and to "/.../ quasi à tutti li Principi dell'Imperio" ${ }^{73}$ From 1665 until 1666 he led the so-called 'Großbotschafft' to Sultan Mehmed IV in order to ratify the peace treaty concluded in Vasvár after the battle at St. Gotthard. ${ }^{74}$ Leslie's embassy was one of the seven Imperial Grand Embassies sent to Constantinople in the $17^{\text {th }}$ century after the signing of the peace treaty in Zsitvatorok in $1606{ }^{75}$ The imperial court selected only important persons for grand ambassadors. ${ }^{76}$ Leslie was selected soon after the signing of the peace treaty in Vasvár, but declined because of his advanced age. ${ }^{77}$ Only after the next person selected, Adolf Ehrenreich Count Puchheim, passed away in October 1664 did Leslie give his consent, on the condition that he be granted the Order of the Golden Fleece. ${ }^{78}$ After months of negotiations, Leslie was accepted among the knights of the Order of the Golden Fleece as their $450^{\text {th }}$ member, ${ }^{79}$ receiving the insignia at the ceremony in the Hofburg on the $6^{\text {th }}$ of May $1665 .^{80}$ The very next day, Leslie and his entourage had their last audience with the Emperor before setting off on their journey. ${ }^{81}$ Elaborate preparations had been taking place for several months, since in accordance with the Emperor's wishes, the embassy was to be more splendid than any other. ${ }^{82}$ Attention was focused on the precious gifts for the sultan, his mother and Ottoman dignitaries, as well as the swell of noblemen invited to accompany the embassy in order to increase its splendour. Leslie's sumptuous entourage included
350 members and 25 noble cavaliers, which was more than previous and later embassies. ${ }^{83}$ Three Turkish tailors were summoned to Vienna to make oriental garments for the entourage. ${ }^{84}$ The grand ambassador and his entourage awoke the admiration of Emperor Leopold I, who commented on their "sumptuous Cavalcade" 85 on the streets of Vienna with the words: "Ist wohl zu sehen gwest, der Pracht ist sehr groß gwest" ${ }^{86}$ His admiration was later shared by Sultan Mehmed IV, who on watching Leslie's entry to Edirne supposedly said that he had never seen such a splendid embassy. ${ }^{87}$

Leslie sat for a portrait for an unknown, presumably Viennese, painter in the diplomatic robes he wore during the parades (Fig. 8). The portrait is preserved in the Náchod Museum, not far from Leslie Castle in Nové Město nad Metují in North-East Bohemia. Petr Landr stated that the portrait was transferred from the Nové Město Museum to Náchod in 1980 and assumed that it was initially hung in the Nové Město convent of the Brothers of Mercy, founded by Walter's nephew Jacob Count Leslie, with the intention of reminding all those who looked at it of the most important member of the founder's family. ${ }^{88}$ Landr's presumption was partially based on the existence of a copy of the portrait, presumably painted in the early $19^{\text {th }}$ century for the convent, when the original was already in poor condition. Unlike Landr, I suggest that the Walter Leslie portrait was intended for his Nové Město castle based on an entry in the castle inventory from 1738 when it was hanging in the dining room: "Ihro excel: herrn herrn graffen Walters von Leslie lebens grösse portrait in Türkischer Kleidung" ${ }^{89}$ Leslie's robes correspond to descriptions in historiographic works and travel journals. ${ }^{90}$ He wears a silver suit and a caftan, both embroidered with golden flowers, while the caftan is lined with sable fur. The insignia of the Order of the Golden Fleece is depicted with great accuracy. The cap of carmine velvet, lined with sable fur and adorned with heron's feathers and a golden rosette with diamonds from the Emperor's treasury, is depicted on the table, alongside the Emperor's authorisation and a pocket watch. It has been pointed out by some researchers that in accordance with the tradition of the Habsburg ambassadors to the sultan, Leslie was wearing the garments of the Hungarian magnates to demonstrate the Emperor's pretensions regarding Hungary, the area of dispute between the two empires. ${ }^{91}$ Foreign garments worn by diplomats can also be considered as an act of politeness, whereas by wearing a Hungarian fur cap instead of a turban, the imperial diplomats could avoid a dispute about rank between the emperor and the sultan, showing themselves to be "merely" royal and not imperial ambassadors. ${ }^{92}$ The presumed political connotation of the Hungarian costume, demonstrating imperial pretensions over the disputed territory, loses some credibility in regard to contemporary reports, which refer to the garments as Turkish. The confusion concerning the Turkish or Hungarian origin of the garments endured until the $20^{\text {th }}$ century, when Carmen Bernis, referring to the robe Sigismund Herberstein was given by the Grand Duke of Moscow, stated that the Muscovites adopted this kind of ceremonial robe from the Turks, whereas the fastening with passementerie was used by the Hungarians, Croats and Turks. ${ }^{93}$ She poses the questions: "Ce furent les hongrois, qui s'inspirèrent des turcs? Ou bien 


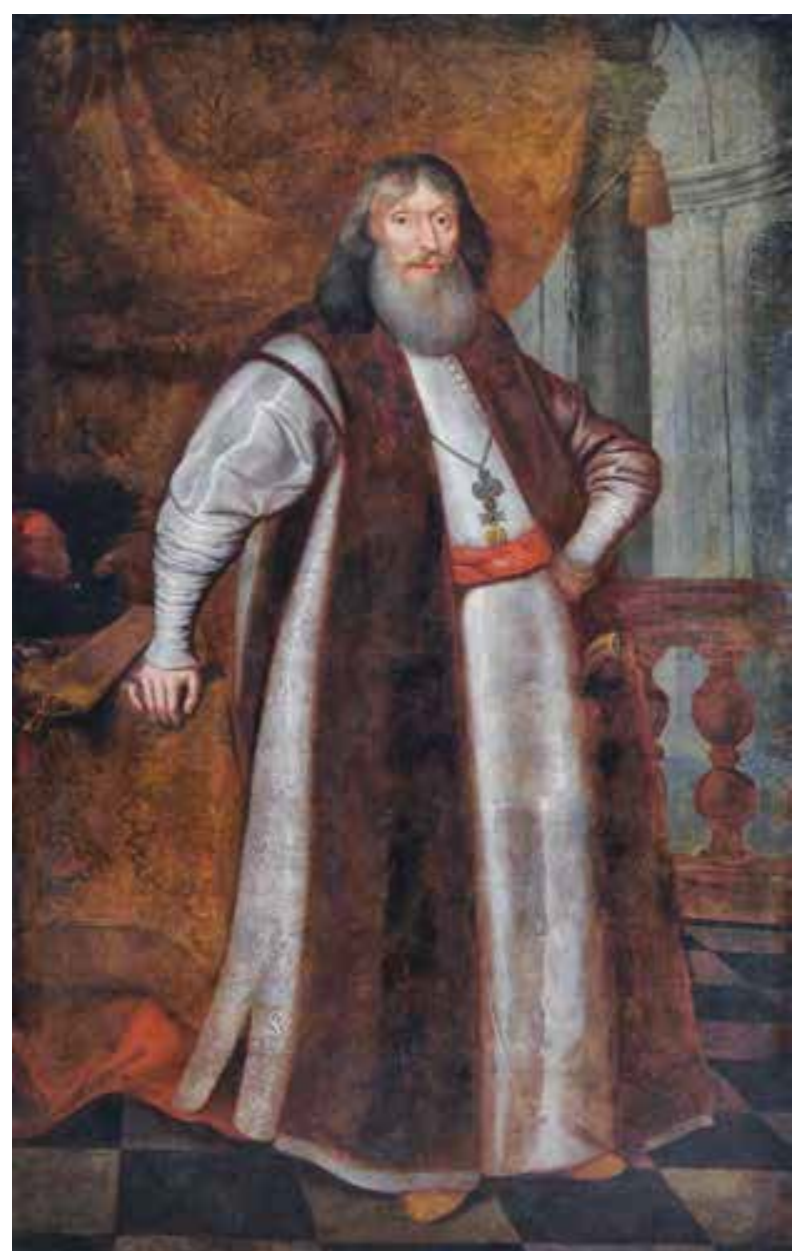

8. Unknown artist (Frans van der Steen?), Walter Count Leslie, 1665-1667, Náchod Museum

Neznani umjetnik (Frans van der Steen?), Grof Walter Leslie, 1665.1667., Muzej Náchod

les turcs s'inspirèrent-ils des hongrois?"94 As already stated, the garments for Walter Leslie and his retinue were made by Turkish tailors and recorded as Turkish in the inventory of Nové Město Castle from 1738. Describing the cavalcade in Vienna, John Burbury states: "But now the Ambassadour, together with his Comrades and their Retinue, being pompously and nobly apparelled after the Turkish fashion, in Cloaths of Gold and Silver." 95 The claim that they were dressed in Turkish and not Hungarian garments can also be made for previous and later ambassadors, for example for Wolfgang IV Count Oettingen-Wallerstein. ${ }^{96}$ Only the fur cap, referred to as a "hochroth-Sammete mit schönem Zobel gebrämbte Türckische Hauben" in the travel journal of Oettingen-Wallerstein's embassy, ${ }^{97}$ was perceived as not being Turkish by some authors, such as in the travel journal of the embassy led by Albrecht Count Caprara in 1687: "Alle die von deß Herrn Abgesandten Gefolge / ritten in Tưrkischem Habit mit Beltzwerck / nach der Weise dieser Nation, voran / und ware kein anderer Unterscheid / als daß sie an Statt deß Turbants gefütterte Kappen und Mùtzen trugen / kòstlichen oder schlechten / nach Beschaffenheit der Personen." ${ }^{98}$ In the engraved frontispiece of this travel journey, the unknown author took the socially distinguishing function of the fur cap into consideration and depicted the members of the retinue with high and narrow fur caps, whereas the ambassador is wearing a turban adorned with jewels and heron's feathers.

Leslie's portrait, which is now in Náchod Museum, was presumably copied in the early $19^{\text {th }}$ century for the convent of the Brothers of Mercy in Nové Město nad Metují (Fig. 9). The copy was later transferred from the convent to the castle and falsely identified as Walter's nephew Jakob Count Leslie, the founder of the convent and hospital of the Brothers of Mercy in Nové Město nad Metují. ${ }^{99}$ The unknown painter copied the portrait accurately but added Leslie's coat of arms in the upper left corner. Petr Landr, who was convinced that the original portrait was also painted for the convent, assumed that the copy was painted due to the poor condition of the original. ${ }^{100}$ The commissioner of the copy and his motives have yet to be determined. The most likely commissioner was Franz Joseph Prince Dietrichstein (1767-1854), the owner of the Nové Město estate from 1808. His father Karl Johann Baptist Prince Dietrichstein (1728-1808) inherited 1802 the title and lands of the last count of Leslie of the CentralEuropean family line. Since then, the full name of the family was Dietrichstein-Proskau-Leslie. Franz Joseph Dietrichstein paid considerable attention to the family portraits. In the early 1840s, Franz Joseph Dietrichstein commissioned downscaled copies of family portraits and some important historical events from the history of the Dietrichstein family by the painter Carl Agricola. ${ }^{101}$ Lithographs were made after Agricola's paintings and printed in 1844 with the title Familien-portraite und Historische Bilder aus dem Fürstlich Dietrichstein'schen Hause. ${ }^{102}$ Apart from twenty portraits of his direct ancestors, Franz Joseph Dietrichstein chose only five other family members to be depicted, among them Walter Leslie in diplomatic robes (Fig. 10). For this reason, we may assume that he also commissioned the copy of the Leslie portrait in Nové Město nad Metují. The copy could have been intended for the convent of the Brothers of Mercy, since an ancestor of Franz Joseph, Ferdinand Prince Dietrichstein, was actively involved in the foundation of the convent in the mid-1690s, which is also demonstrated by his coat of arms over the main entrance into the convent.

Another painted portrait of Walter Leslie in diplomatic robes existed in Mikulov Castle, possessed by the Dietrichstein family; it appears in inventories and paintings lists until the beginning of the $20^{\text {th }}$ century, but it has not been preserved. ${ }^{103}$ In a list of paintings in Mikulov Castle, drafted in 1861, it is referred to as "Portrait: Graf Leslie im türkischen Kostüm". ${ }^{104}$ The estimated value of 15 florins, compared with the value of the other portraits mentioned in the list, is evidence that it was a full body portrait. As all the other downscaled copies of the family portraits by Carl Agricola were copied in Mikulov Castle, we may assume that Agricola copied the Leslie portrait in Mikulov and not the one in Nové Město nad Metují. According to the lithograph, the portraits in Mikulov and in Nové Město can be considered replicas, presumably both commissioned by Walter Leslie himself. As already stated, one was intended for his Nové Město castle and the other came into the possession of the Dietrichstein family. The portrait in Mikulov was probably identical to the "Contra- 


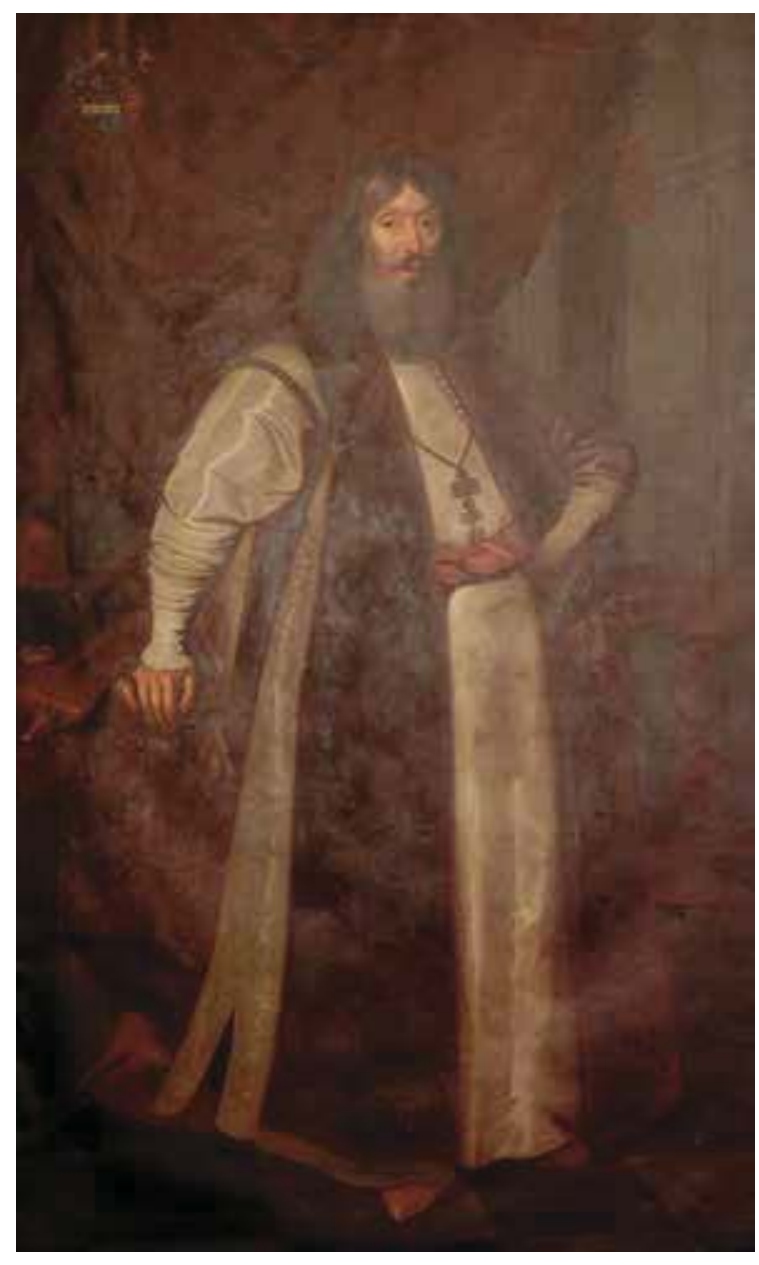

9. Unknown artist, Walter Count Leslie, Nové Město nad Metují Castle Neznani umjetnik, Grof Walter Leslie, dvorac Nové Město nad Metují

fait des herrn Graffen Leslie Lebensgroß", mentioned in the probate inventory of Leslie's widow Anna Francisca, born Countess of Dietrichstein. ${ }^{105}$ She bequeathed all her possessions to her nephew Walter Xaver Count Dietrichstein, but her brother, Ferdinand Prince Dietrichstein, selected some paintings for his own collection in Mikulov Castle, among them the portrait of Walter Leslie.

After the portrait in Nové Město or in Mikulov, Leonard Henry van Otteren made a copper engraving published in Historia di Leopoldo Cesare by Galleazzo Gualdo Priorato in 1670 (Fig. 11). ${ }^{106}$ The inscription mentions Leslie's positions of a councillor of state, Knight of the Golden Fleece, the imperial general in Slavonia and Grand Ambassador to the Ottoman Porte ("Gvaltiero Conte di Leslie del Cons. Di Stato di S. M. Ces. Generale in Schiavonia, Cavalier del Toson, Ambasciatore Straordinario alla Porta Ottomana"). The signature "Leonardo Hen-(co)-V-O Venetiis" was falsely deciphered as Leonard Venetiis, but the last part of the signature probably indicates the making of the engraving in Venice.

Paul Tafferner, a Jesuit who accompanied Walter Leslie to Constantinople, published a travel journal in Vienna in 1668. ${ }^{107}$ The travelogue was written in Latin and dedicated

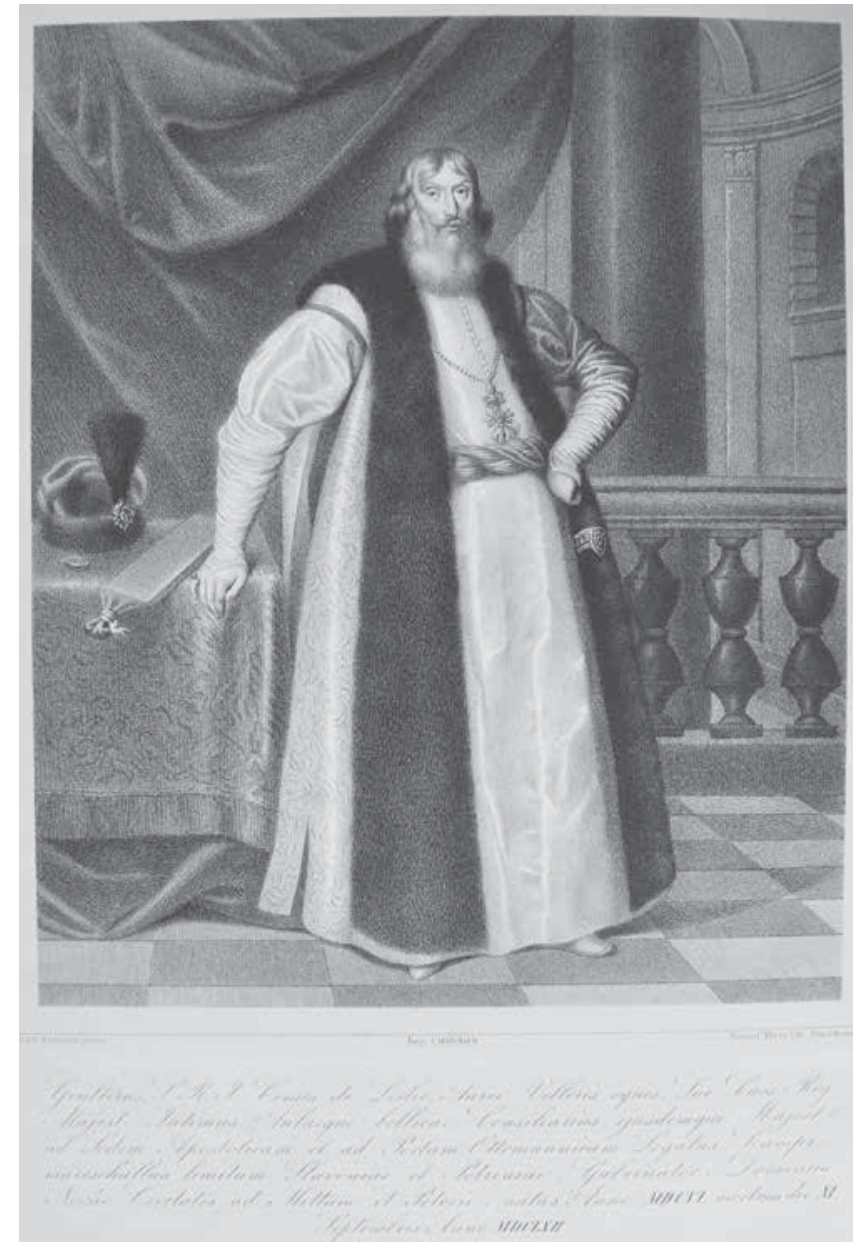

10. Robert Theer after Karl Agricola, Walter Count Leslie, lithograph, in: Familien-portraite und Historische Bilder aus dem Fürstlich Dietrichstein'schen Hause, 1844, Státní oblastní archiv v Zámrsku

Robert Theer prema Karlu Agricoli, Grof Walter Lesli, litografija, u: Familien-portraite und Historische Bilder aus dem Fürstlich Dietrichstein'schen Hause, 1844., Državni regionalni arhiv u Zámrsku

to the ambassador's nephew Jacob Count Leslie. ${ }^{108}$ The sole illustration in the travelogue is a portrait of the ambassador with the inscription "Gualterus S. R. I. Comes de Leslie Cæsareus ad Portam Ottomanicam Orator” (Fig. 12). The engraving was probably made by Frans van der Steen, who signed his work with the initials "F. v. s. S. C. M. f." Van der Steen's works for Walter Leslie are not documented, but from August 1665 until July 1667, van der Steen was in contact with Leslie's friend Karl Eusebius Prince Liechtenstein, to whom he sold a painting and some copper engravings. ${ }^{109}$ There is a possibility that Frans van der Steen is also the author of the painted portraits in Nové Město nad Metuji and Mikulov, but there is no written evidence relating to it and no known paintings by van der Steen for comparison. ${ }^{110}$ It was probably Paul Tafferner who commissioned the engraved portrait of Walter Leslie and prepared the inscriptions, since Walter Leslie died in 1667. As in the painted portraits, Leslie is depicted in diplomatic robes and with the Order of the Golden Fleece, but with the addition of depicted objects, background scenes and inscriptions, the 


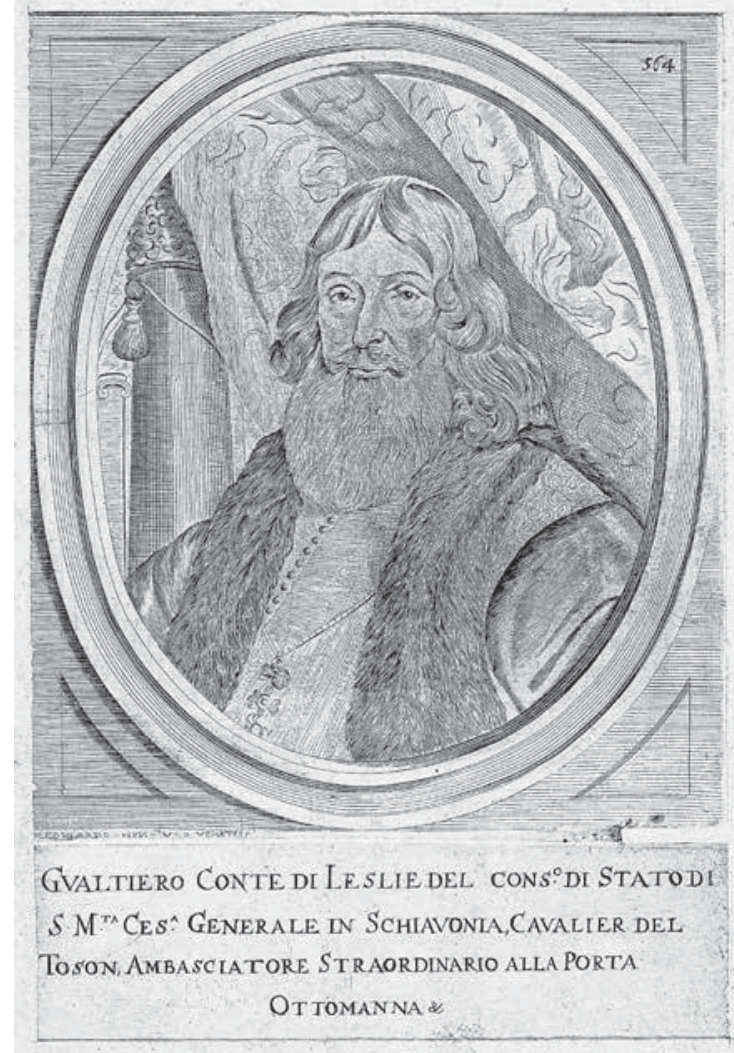

11. Leonard Henry van Otteren, Walter Count Leslie, engraving, in: Historia di Leopoldo Cesare, 2, 1670, Vienna, Austrian National Library

Leonard Henry van Otteren, Grof Walter Leslie, bakrorez, u: Historia di Leopoldo Cesare, 2, 1670., Beč, Austrijska nacionalna biblioteka

message of the portrait was significantly extended. ${ }^{111}$ The engraver left out the emperor's authorisation, leaving only the fur cap with heron's features and a small chest on the table. On the wall behind the table is a cartouche adorned with a laurel wreath and the inscription "CæsarI In mIs oMnI hora fIDeLIs serVIVI”, giving the year 1668. Walter Leslie points with a baton to a battlefield depicted in the background. The military aspect is accentuated with a helmet and a cuirass lying at the ambassador's feet, while a sword, a trumpet and a laurel wreath on the pedestal embellished with Leslie's coat of arms remind us of the ambassador's justice and fame. An eagle in the upper left corner holds Jupiter's thunderbolts and Mercury's caduceus, symbolising - according to Friedrich Polleroß - the function of an imperial diplomat. ${ }^{112}$ The eagle is accompanied by two angels holding bands with the inscriptions "Vtrvm libet" and "Vtrvmqve". They refer to the heroic device "Vtrum libet" (Whether it pleases) published by Claude Paradin in 1551 and as a whole emblem with a motto, image and text in $1557 .{ }^{113}$ Paradin's image consists of a mace wrapped with an olive branch. According to Paradin's explanatory text, the mace wrapped with an olive branch could be shown to one's enemies, offering them a choice of war or peace, just as the Romans had shown a caduceus and a lance to their enemies. ${ }^{114}$ An engraving by Frans van der Steen after Gerard Bouttats with a similar connotation was published as a frontispiece to the second part of Historia di

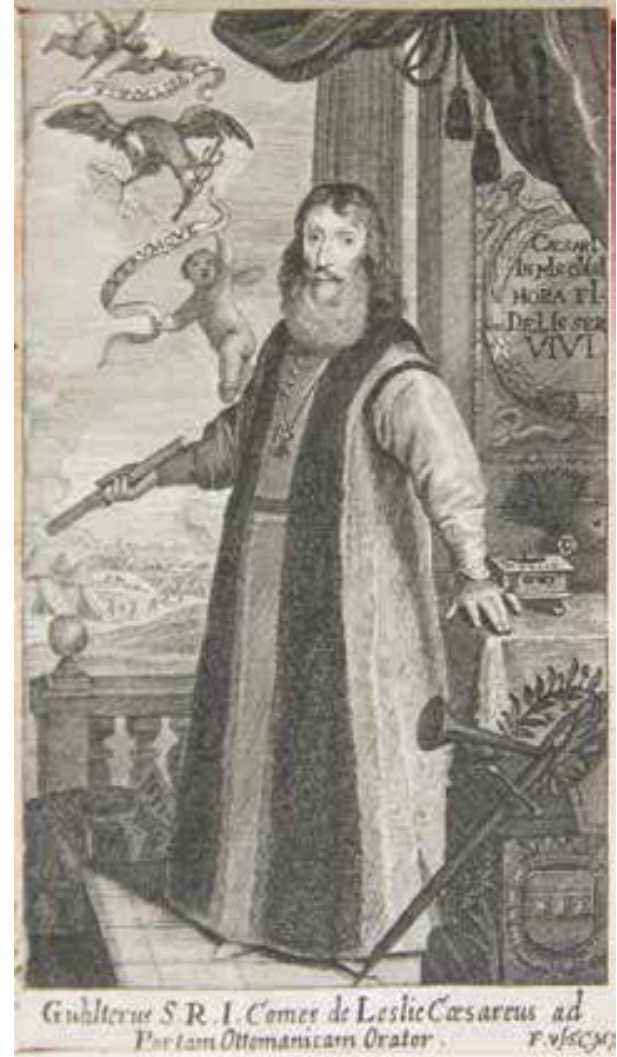

12. Frans van der Steen, Walter Count Leslie, 1668, engraving, in: Cosarea legatio, quam Mandante Augustissimo Rom: Imperatore Leopoldo I., 1668, Státní oblastní archiv v Zámrsku

Frans van der Steen, Grof Walter Leslie, 1668., bakrorez, u: Cæsarea legatio, quam Mandante Augustissimo Rom: Imperatore Leopoldo I., 1668., Državni regionalni arhiv u Zámrsku

Leopoldo Cesare: the imperial eagle is holding thunderbolts and an olive branch in his bill; the thunderbolts from his right paw are killing the Ottomans, whereas the leaves from the olive branch in his left paw are falling on a group of peaceful looking Ottomans. ${ }^{115}$ Under the eagle is the inscription "Sternit, et Vnit". Regarding the Leslie portrait, the militaristic standpoint of the presumed commissioner Paul Tafferner is obvious: whereas the imperial eagle shows thunderbolts and a caduceus to the Ottomans, Leslie is unequivocally pointing to a battlefield. The message of the engraved portrait seems at odds with the diplomatic mission of Walter Leslie, sent to Constantinople to ratify a peace treaty. However, Leslie, as vice-president of the Aulic War Council, surely shared the militaristic standpoint toward the Ottomans with the Jesuit Tafferner, since they, as Philip Steiner pointed out, shared both a religious and cultural disdain for Ottoman culture. ${ }^{116}$

A more reconcilable visual answer to the militaristic illustration in the Latin edition of Tafferner's travelogue can be found in an unauthorized German edition published in $1672 .{ }^{117} \mathrm{It}$ is illustrated with an etched allegory entitled "Keÿserliche Botschafft" (Fig. 13). ${ }^{118}$ The portraits of Walter Leslie and the Ottoman ambassador to the imperial court are depicted in medallions framed with laurel wreaths and fastened to columns, with one column embellished with a crown, a sceptre and a sword, and the other with a turban, a sceptre and a sabre. The symbols of the two empires are supplemented by a church and 


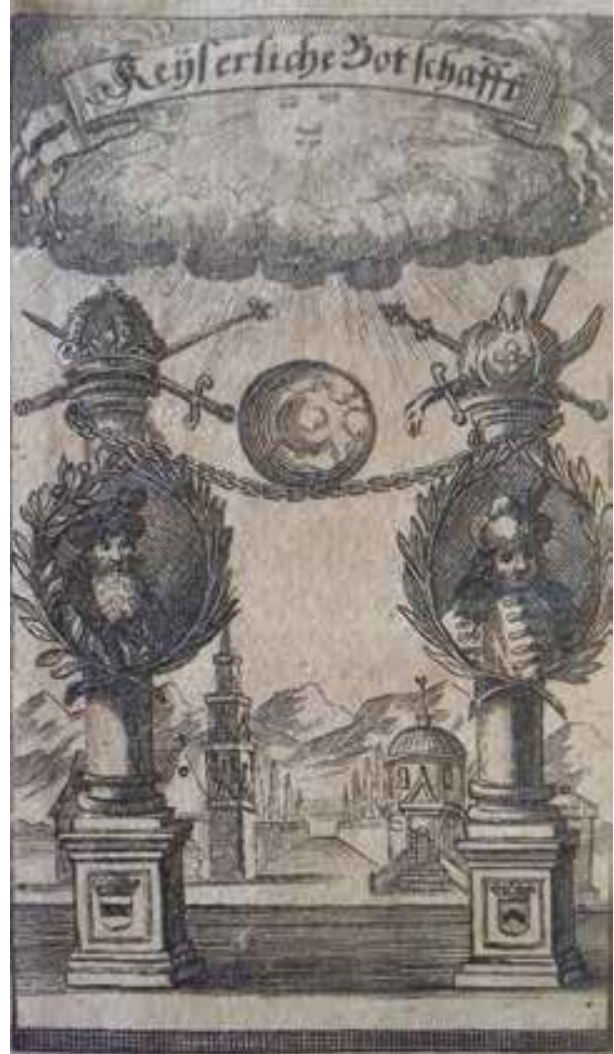

13. Unknown artist, Kaÿserliche Botschaft, engraving, in: Keiserliche Botschaft an die Ottomanische Pforte, 1672, Vienna, Austrian National Library

Neznani umjetnik, Carsko poslanstvo, bakrorez, u: Keiserliche Botschafft an die Ottomanische Pforte, 1672., Beč, Austrijska nacionalna biblioteka

a mosque in the background. As a sign of peace, the columns are linked together with a chain on which the globe balances, while the sun shines equally upon both countries. ${ }^{119}$ The message of the allegory echoes the main intention of the Grand Embassies travelling between Vienna and Constantinople since the peace treaty of Zsitvatorok in 1606 , i.e. symbolizing the equivalence of the power of both empires. ${ }^{120}$

Paul Tafferner was unhappy with the unauthorized German edition, claiming it contained numerous mistakes and "so vil Lutherische Lehrsprüch". ${ }^{121} \mathrm{He}$ arranged a new translation by the erudite Joannes Georg Schliessel and published it in Vienna with a dedication to the ambassador's widow Anna Francisca. ${ }^{122}$ Although Tafferner only criticised the translation, he was obviously also unhappy with the illustration, since he commissioned a new etched allegory to illustrate the new German edition (Fig. 14). The portrait of Walter Leslie is omitted and the message of the allegory is even more militaristic, intolerant and at odds with the intentions of Grand Embassies, similar to the illustration of the Latin edition. An eagle with the device of Emperor Leopold I ("Consilio et Indvstria") sticks Jupiter's thunderbolts into a dragon symbolising the Ottoman Empire. The eagle holds a raised sword in its second paw and the victorious battle at St. Gotthard ("S. Gothard") is depicted in the background. The personification of Fame holding a band with a verse from Psalm 121 floats over the eagle ("Fiat Pax in virtute tua"). ${ }^{123}$

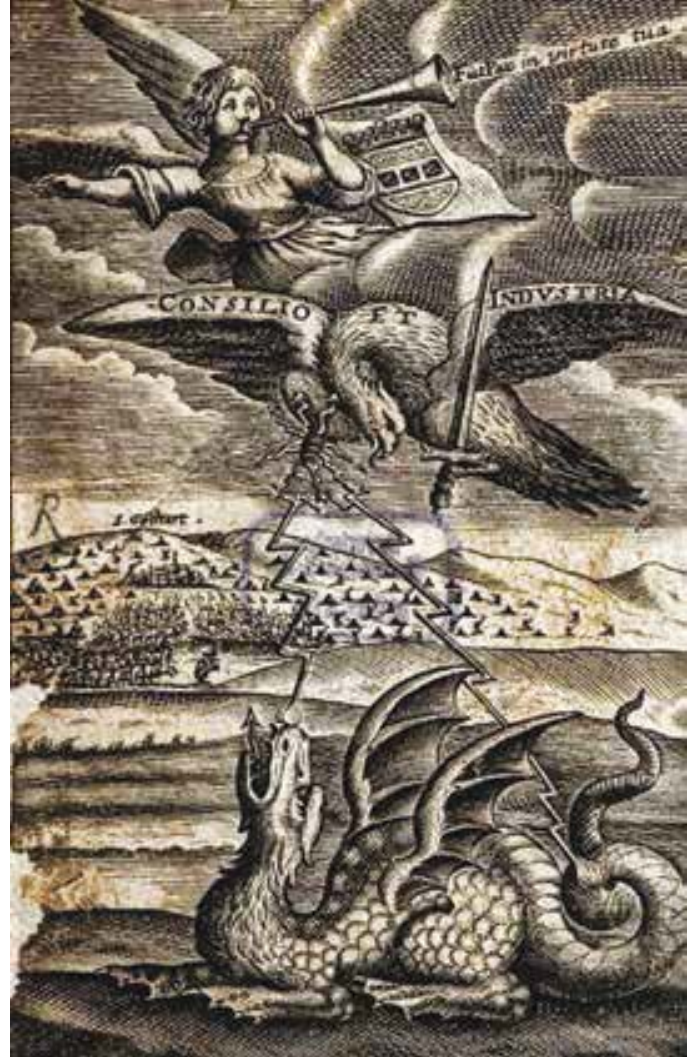

14. Unknown artist, Frontispiece, engraving, in: Der Röm: Kay: May: Leopoldi I. An Deß grossen TürckenSultans, [s. d.], Munich, Bavarian State Library

Neznani umjetnik, frontispis, bakrorez, u: Der Röm: Kay: May: Leopoldi I. An Deß grossen TürckenSultans, [s. d.], München, Bavarska državna knjižnica

This general view of the relations between both empires becomes more personal with the addition of Leslie's coat of arms onto the flag fastened to Fame's trumpet. Silk flags with Leslie's coat of arms were fastened to the trumpets and drums played during Leslie's parades, for instance during his solemn entry into Edirne. ${ }^{124}$

Just as with the portraits conveying the virtues of famous ancestors, the diplomatic robes and presents received by Ottoman dignitaries were also carefully kept by the heirs of both diplomats. A cloakroom with precious Spanish and oriental garments is reported in the Herberstein castle in Styria. ${ }^{125}$ "Unterschiedliche türkische Zeug, nebst einen türkischen Kleyd" are mentioned in the probate inventory of Leslie's great nephew Jacob Ernst Count Leslie in the "feuer Gewölb" of his Graz palace in 1737. ${ }^{126}$ The precious Turkish robes could also have been remade into liturgical vestments. In 1684, a nephew of the Grand Ambassador, the Jesuit Willem Aloisius Count Leslie, wrote to his brother Jacob that the Loreto chapel and the parish church in Nové Město nad Metují lacked liturgical vestments and suggested that some Turkish robes stored in the castle cloakroom be remade ("....and as for vestments both for it (Lauret Chappell) and the church, which hath also much need, your Exce might make imploy some of our Unckles turkish cloaths which otherwayes rotts in your Guardarobbe..."). ${ }^{127}$ Either depicted or preserved in the original, diplomatic robes were an effective medium of self-representation. ${ }^{128}$ 


\section{Notes}

* This paper is an extended and elaborated version of work presented at the conference The Power of Media. Patronage, Representation and Propaganda in Early Modern Period (1450-1800) between the Mediterranean and Central Europe (Split, June 13-15, 2018).

1

NINA TRAUTH, Maske und Person. Orientalismus im Porträt des Barock, Berlin - München, 2009, 259-260.

2

FRIEDRICH POLLEROß, Gesandte im Bild. Repräsentationsformen der Diplomatie, in: GUNDA BARTH-SCALMANI HARRIET RUDOLPH - CHRISTIAN STEPPAN (eds.), Politische Kommunikation zwischen Imperien. Der diplomatische Aktionsraum Südost- und Osteuropa (Innsbrucker historische Studien, 29), Innsbruck, 2013, 41-67.

3

On the diplomatic mission of Sigismund Herberstein and Nicolaus Count Salm-Neuburg, see: ERNST D. PETRITSCH, Die diplomatischen Beziehungen Ferdinands I. mit den Osmanen. Techniken und Probleme, in: GERHARD PFERSCHY (ed.), Siegmund von Herberstein. Kaiserlicher Gesandter und Begründer der Rußlandkunde und die europäische Diplomatie (Veröffentlichungen des Steiermärkischen Landesarchives, 17), Graz, 1989, 89-99.

4

FRIEDRICH POLLEROß (note 2), 49.

5

ARNO STROHMEYER, Text and Picture in Habsburg Diplomacy at the Sublime Porte $\left(16^{\text {th }}-18^{\text {th }}\right.$ centuries $)$, in: Teкcm $i$ образ: актуальні проблеми історії мистеитва [Text and Image: Essential Problems in Art History], 1 (2016), 7-23, here 11.

6

POLONA VIDMAR, Diplomat in njegova imenitna oblačila. Ilustracije v Herbersteinovih Gratae posteritati [The Diplomat and His Valuable Robes. Illustrations in Herberstein's Gratae Posteritati], in: MIRA PETROVIČ - MATJAŽ NEUDAUER (eds.), Gratae posteritati. Študijska izdaja, Maribor, 2014, 234-254, here 246-250. 7

JOSEF WÜNSCH, Der Wiener Maler und Formschneider Donat Hübschmann, in: Mitteilungen der Gesellschaft für vervielfältigende Kunst. Beilage der "Graphischen Künste”, 1 (1913), 1-13, here 2; TILMAN FALK (ed.), Hollstein's German Engravings, Etchings and Woodcuts 1400-1700, vol. XV A: Lambert Hopfer to Sebastian Jenet, Roosendaal, 1986, 109-111.

8

WALTER LEITSCH, Probleme bei der Edition von Herbersteins Moscovia, in: GERHARD PFERSCHY (ed.), Siegmund von Herberstein. Kaiserlicher Gesandter und Begründer der Rußlandkunde und die europäische Diplomatie (Veröffentlichungen des Steiermärkischen Landesarchives, 17), Graz, 1989, 165-177, here 173.

9

FRIEDRICH POLLEROß (note 2), 54.

10

Gratae posteritati Sigismvndvs liber baro in Herberstain Neyperg \& Guettenhag, Primarius Ducatus Carinthice Hoereditariusq: \& Camerarius \& Dapifer \& c. Immunitate meritorum ergo donatus, actiones suas à puero ad annum vsq: atatis suce septuagesimum quartum, breui commentariolo notatas reliquit, Viennæ, 1560, [94]. 11

ALFRED NEHRING, Hirsfogel's Beziehungen zu Herberstein's Werken, in: Repertorium für Kunstwissenschaft, 20 (1897), 121129; KARL SCHWARZ, Augustin Hirschvogel. Ein deutscher Meister der Renaissance. Text, Berlin, 1917, 29-30; POLONA VIDMAR (note 6), 235.
12

ALFRED NEHRING (note 11), 121-129; TILMAN FALK (ed.), Hollstein's German Engravings, Etchings and Woodcuts 1400-1700, vol. XIII A: Jacob van der Heyden to Nicolaus Hogenberg, Roosendaal, 1984, 186-187, 216, 225-239.

13

TILMAN FALK (note 12), 237.

14

HORST KUNZE, Geschichte der Buchillustration in Deutschland. Das 16. und 17. Jahrhundert, Frankfurt am Main, 1993, 452.

15

JOHN L. NEVINSON, Siegmund von Herberstein. Notes on $16^{\text {th }}$-Century Dress, in: Waffen- und Kostümkunde, Dritte Folge, 1. Bd./1 und 2 (1959), 86-93, here 92.

16

TILMAN FALK (note 7), 226-229.

17

ALFRED NEHRING (note 11), 128.

18

TILMAN FALK (note 7), 234-236.

19

POLONA VIDMAR (note 6), 243.

20

THEODOR GEORG VON KARAJAN (ed.), Selbst-Biographie Siegmunds Freiherrn von Herberstein. 1486-1553, in: Fontes rerum Austriacum, I, 1, Wien, 1855, 67-396.

21

KARL A. E. ENENKEL, Die Erfindung des Menschen. Die Autobiographik des frühneuzeitlichen Humanismus von Petrarca bis Lipsius, Berlin - New York, 2008, 546-574, here 546, 550.

22

Sigmund Freyherr zu Herberstain Neyperg / vnd Guttenhag / oberster ErbCammer vnd oberster Drucksas in Kärnten. Den Gegenwurtign vnd nachkomenden freyherrn zu herberstain. Seines thuns dienstn vnnd Raisens mit trewer vermannung sich zu Tugenden vnnd guetem weesn schicken, Wienn, [1559].

23

Gratae posteritati (note 10).

24

Pictvrae variae Quae Generosum ac Magnificum Domi. Dominum Sigismundum liberum Baronem in Herberstain Neyperg \& Guttenhag etc. varias legationes obeuntem exprimunt, Viennæ, 1560. 25 Sigmund Freyherr zu Herberstain (note 22), title page.

26

KARL A. E. ENENKEL (note 21), 548; MATEJ HRIBERŠEK, Majhno, a pomembno ogledalo svojega časa: Herbersteinovo delo Gratae posteritati [A Small yet Important Witness of its Time: The Herberstein's Gratae posteritati], in: MIRA PETROVIČ - MATJAŽ NEUDAUER (eds.), Gratae posteritati. Študijska izdaja, Maribor, 2014, 178-205, here 205.

27

KARL A. E. ENENKEL (note 21), 560; MATEJ HRIBERŠEK (note 26), 205.

28

JOHN L. NEVINSON (note 15), 91-92; WALTER LEITSCH (note 8$), 174$

29

JOHN L. NEVINSON (note 15), 91-92. 
30

Itinerarivm Wegrayß kü. May. Potschafft / gen Constaninopel / $z$ ů dem Türckischen Kayser Soleyman. Anno XXX, 1531. On the diplomatic mission, see: ERNST D. PETRITSCH (note 3), 91.

31

ERIK FISCHER, Melchior Lorck, 1, Kopenhagen. 2009, pp. 87-89; FRIEDRICH POLLEROß (note 2), 42-43.

32

See KARL A. E. ENENKEL (note 21), 566.

33

De historia stirpivm commentarii insignes, maximis impensis et vigiliis elaborate, adiectis earvndem vivis plvsqvam quingentis imaginibus, nunquam antea ad naturae imitationem artificiosius effictis \& expressis Leonharto Fvchsio medico hac nostra oetate longe clarissimo, autore (...), Basileae, 1542. For the book and the portrait see: BRIGITTE BAUMANN - HELMUT BAUMANN (eds.), Das Kräuterbuchhandschrift des Leonhart Fuchs, Stuttgart, 2001. 34

The location of Herberstein's house in Vienna is not certain. Friedrich Adelung mentioned only that Herberstein had resided in Vienna when he was not on his diplomatic missions (see: FRIEDRICH ADELUNG, Siegmund Freiherr von Herberstein. Mit besonderer Ruecksicht auf seine Reisen in Russland, St. Petersburg, $1818,279)$. A house in the Herrengasse is mentioned by Nevinson, though without quotation - JOHN L. NEVINSON (note 15), 92. 35

On poets who contributed their works for Gratae posteritati, see MATEJ HRIBERŠEK (note 26), pp. 186-191.

36 Gratae posteritati (note 10), [94].

37

Ibid.

38

Ibid. [95].

39

Ibid. [101].

40 Ibid. [101].

41

POLONA VIDMAR (note 6), 247.

42

On the colours in different copies, see: JOHN L. NEVINSON (note 15), 87-90.

43

JOHN L. NEVINSON (note 15), 92.

44

MATEJ HRIBERŠEK, Prevod dela Ljubemu zanamstvu (Gratae posteritati), in: MIRA PETROVIČ - MATJAŽ NEUDAUER (eds.), Gratae posteritati. Študijska izdaja, Maribor, 2014, 1-118, here 76: "(...) doma dveh živali koži pred rodni kamin dal razgrniti si je." 45

INGRID HALÁSZOVÁ, Einleitung: Das Phänomen des Porträts und die Gestaltung der adeligen Porträtgalerien im 16. und 17. Jahrhundert in den Ländern der ehemaligen Habsburgermonarchie, in: INGRID HALÁSZOVÁ (ed.), Die Noblesse im Bild. Die adeligen Porträtgalerien in der Frühen Neuzeit in den Ländern der ehemaligen Habsburgermonarchie (Spectrum Slovakia Series, 13), Frankfurt am Main - Bratislava, 2016, 11-37, here 15.

46

INGRID HALÁSZOVÁ (note 45), 17.
47

Ibid., 17; see also: BLANKA KUBÍKOVÁ, Die Anfänge der Porträtgalerie in Böhmen und Mähren, die Sammlungen der Familien Neuhaus und Rosenberg, in: INGRID HALÁSZOVÁ (ed.), Die Noblesse im Bild (note 45), 39-74, here 49.

48

BLANKA KUBÍKOVÁ (note 47), 46-49.

49

FRIEDRICH POLLEROß, "Freundschafftszimmer". Die Familiengalerie der Grafen Lamberg auf Schloss Ottenstein im 17. Jahrhundert, in: INGRID HALÁSZOVÁ (ed.), Die Noblesse im Bild (note 45), 225-239, here 227.

50

INGRID HALÁSZOVÁ (note 45), 18.

51

JOSEF VON ZAHN (ed.), Das Familienbuch Sigmunds von Herberstein. Nach dem Originale herausgegeben, in: Archiv für Kunde österreichischen Geschichtsquellen, 39 (1868), 293-415.

52

KARL A. E. ENENKEL (note 21), 553-554.

53

JOHN L. NEVINSON (note 15), 90.

54

Gratae posteritati (note 10), [33].

55

Pictvrae variae (note 24), [22].

56

Sigmund Freyherr zu Herberstain (note 22), [38].

57

Gratae posteritati (note 10), [34].

58

Pictvrae variae (note 24), [24].

59

Sigmund Freyherr zu Herberstain (note 22), [39].

60

ERNST D. PETRITSCH (note 3), 96.

61

JENNIFER WEARDEN, Siegmund von Herberstein; An Italian Velvet in the Ottoman Court, in: Costume. The Journal of the Costume Society, 19 (1985), 22-29, here 25.

62

KARL A. E. ENENKEL (note 21), 563. The founder of Hrastovec portrait gallery, now displayed in Ptuj castle, was probably Johann Ernst II. Herberstein; see: TINA KOŚAK, Slikarske zbirke grofov Herberstein. Zbirki Janeza Ernesta I. in Janeza Ernesta II. v Gradcu in gradu Hrastovec, in: Acta historiae artis Slovenica, 20/1 (2015), 97-137, here 111-112, 115 .

63

FRIEDRICH POLLEROß (note 2), 53.

64

Neu-eroffneten Historischen Bilder=Saals, Sechster Theil. Das ist: Kurtze / deutliche und unpassionirte Beschreibung der historiae universalis enthaltend die Geschichten / so annoch unter dem glorwurdigsten Kaiser Leopoldo I. biß auf die Regierung Kaisers Josephi I. in Europa, auch sonsten in der Welt / sich hin und wieder zugetragen (...), Nưrnberg 1710, 162.

65

Neu-erofffneten Historischen Bilder=Saals (note 64), 162: “(..) denn dem Frantzo̊sischen Ambassadeur ist allein an dem Tưrckischen Hof vergo̊nnt / in Franzo̊sicher Tracht zu erscheinen / da hingegen alle andere Gesandtschafften sich der Türckischen bedienen můssen (...)." 


\section{6}

Neu-eröffneten Historischen Bilder=Saals (note 64), 163: "Weil nun Feriole den Degen nicht ablegen wollte / wurde ihm die Audientz versagt / worauf er den von denen Tưrcken empfangenen Ehrenrock oder Caftan nebst seiner Suite ablegte (...)".

67

See: MARIA ELISABETH PAPPE, Turquerie im 18. Jahrhundert und der "Recueil Ferriol", in: GEREON SIEVERNICH - HENDRIK BUDDE (ed.), Europa und der Orient 800-1900, Berlin 1989, 305-323, here 323.

68

On the ceiling painting in the main hall of the Chateau Trpisty in West Bohemia, see: MARTIN MÁDL, Images of Turks in the Baroque Ceiling Decorations of the Czech Land and Their Central European Context, in: ECKHART LEUSCHNER - THOMAS WÜNSCH (eds.), Das Bild des Feindes. Konstruktion von Antagonismen und Kulturtransfer im Zeitalter der Türkenkriege. Ostmitteleuropa, Italien und Osmanisches Reich, Berlin, 2013, 95-114, here 112. 69

\section{FRIEDRICH POLLEROß (note 2), 53.}

70

A Relation of a Journey of the Right Honourable My Lord Henry Howard, From London to Vienna, and thence to Constantinople; In the Company of his Excellency Count Lesley, Knight of the Order of the Golden Fleece, Councellour of State to his Imperial Majesty, etc. And Extraordinary Ambassadour from Leopoldus Emperour of Germany to the Grand Signior, Sultan Mahomet Han the Fourth. Written by John Burbury Gent., London 1671, A3r-A4v.

71

BERTOLD PICARD, Herberstein als habsburgischer Diplomat, in: GERHARD PFERSCHY (ed.), Siegmund von Herberstein. Kaiserlicher Gesandter und Begründer der Rußlandkunde und die europäische Diplomatie (Veröffentlichungen des Steiermärkischen Landesarchives, 17), Graz, 1989, 101-116, here 101.

72

For Leslie's missions in 1639 and 1645 see DAVID WORTHINGTON, Scots in Habsburg Service, 1618-1648 (History of Warfare, 21), Leiden - Boston, 2004, 217-218, 256-257.

73

Historia di Leopoldo Cesare, descritta dal co: Galleazzo Gualdo Priorato, dedicata Alla Sacra Cesarea, Real Maestà dell'Imperatrice Leonora. Postoui li Ritratti de Principi, Generali, gl' Assedij di Piazze, con le Scritture, Trattati, e Capitulationi nel fine. Parte seconda, Vienna 1670, 564.

74

For an analysis of the peace treaty, see: GEORG WAGNER, Das Türkenjahr 1664. Eine europäische Bewährung. Raimund Montecuccoli, die Schlacht von St. Gotthard-Mogersdorf und der Friede von Eisenburg (Vasvár) (Burgenländische Forschungen, 48), Eisenstadt, 1964, 430-484.

75

JOSEPH HAMMER, Geschichte des Osmanischen Reiches, 6: Von der Grosswesirschaft Mohammed Köprili's bis zum Carlowiczer Frieden. 1656-1699, Pest, 1830, 164.

76

PHILIP STEINER, Zwischen religiösen Vorbehalten und diplomatischem Pflichtgefühl. Die habsburgische Grossbotschaft unter Walter Leslie an die Hohe Pforte (1665-1666), in: Historisches Jahrbuch, 132 (2012), 276-303, here 280.

77

Historia di Leopoldo Cesare (note 73), 564.

78

Historia di Leopoldo Cesare (note 73), 564-565; PHILIP STEINER, Die habsburgische Großbotschaft unter Walter Leslie anhand des
Reiseberichts des jesuitischen Gesandtschaftskaplan Paul Tafferner (1665/66), in: KARIN SPERL - MARTIN SCHEUTZ - ARNO STROHMEYER (eds.), Die Schlacht von Mogersdorf/St. Gotthard und der Friede von Eisenburg/Vasvár. Rahmenbedingungen, Akteure, Auswirkungen und Rezeption eines europäischen Ereignisses (Burgenländische Forschungen, 108), Eisenstadt, 2016, 233-291, here 245. 79

Le Blason des Armoiries de tous les Chevaliers de l'Ordre de la Toison d'or depvis la premiere institvtion ivsques à present. Avec leurs noms, surnoms, titres, \& cartiers, Ensemble leurs Eloges descrites en bref, Le tout recuelly par Jean Baptiste Mavrice, Heraut \& Roi D’Armes de sa Maiesté Catholique, La Haye - Bruxelles, 1667, 494.

80

For a description of the ceremony, see: Der Röm: Kay: May: Leopoldi I. An Deß grossen TürckenSultans Mehemet Cham Ottomanische Porten Anno 1665. den 25. May abgeordnete Bottschafft / Welche Ihro Hochgrafl: Excellenz / etc Herr Herr Walther Leßlie / deß Heil. Röm: Reichs Graff und Herr zu Pettau und Newstatt an der Mettau / Ritter deß goldenen Fluß / der Röm: Kays. May: Gehaimer Rath / Hoff=Kriegs $=$ Rath $/$ Feld $t=$ Marschall $/$ und über die Windisch und Petrinische Granitz General / denckwürdig verrichtet Und von P. Paulo Tafferner der Societät Jesu Priester / ernent Ihrer hochgräfl: Excellenz gewester Raiß=Caplan / Anno 1668. Lateinisch zu Wienn / anjetzo aber dem günstigen Leser zu Belieben in Teutsch verfasset, Wienn, [1672], 3-7.

81

Historia di Leopoldo Cesare (note 73), 565-568; Der Röm: Kay: May: Leopoldi I. An Deß grossen TürckenSultans (note 80), 7-8.

82

Historia di Leopoldo Cesare (note 73), 565.

83

JIŘÍ KUBEŠ, Diplomat a jeho lidé, in: JIŘÍ KUBEŠ (ed.) V zastoupení císaře. Česká a moravská aristokracie v Habsburské diplomacii 1640-1740, Pardubice, 2018, 71-99, here 91.

84

NINA TRAUTH (note 1), 251.

85

A Relation of a Journey (note 70), 31.

86

ALFRED FRANCIS PRIBRAM - MORIZ LANDWEHR VON PRANGENAU (eds.), Privatbriefe Kaiser Leopold I. an den Grafen F. E. Pötting, 1: November 1662 bis Dezember 1668 (Fontes rerum Austriacum, Diplomataria et acta, 56), Wien, 1903, 123.

87

Der Röm: Kay: May: Leopoldi I. An Deß grossen TürckenSultans (note 80 ), 80 .

88

PETR LANDR, Nově zrestaurovaný portrét Waltra z Leslie. <https://www.muzeumnachod.cz/index.php/2016/10/25/375/> (3 March 2019).

89

Státní oblastní archiv v Zámrsku, Roddiny archiv Lesliů, kt. 14, inv. č. 318, Inventory of the castle Nové Město nad Metují, 3 June 1738 , fol. $6 \mathrm{v}$.

90

Historia di Leopoldo Cesare (note 73), 568; Der Röm: Kay: May: Leopoldi I. An Deß grossen TürckenSultans (note 80), 78.

91 IGOR WEIGL, In a Caftan before the Emperor, with the Haiduks around Graz and with a Library in Ptuj. The Counts Leslie and their City and Country Residences in the $17^{\text {th }}$ and the $18^{\text {th }}$ Century, in: POLONA VIDMAR (ed.), Zapuščina rodbine Leslie na 
ptujskem gradu, Ptuj, 2002, 88-96, here 89; NINA TRAUTH (note 1), 252-253; FRIEDRICH POLLEROß (note 2), 52.

92

FRIEDRICH POLLEROß (note 2), 52.

93

CARMEN BERNIS, Échanges pendant la Renaissance, entre les modes espagnoles et le modes de L'Europe centrale et orientale (hongroise, albanaise et turque), in: GYÖRGY RÓSZA (ed.), Actes du XXII congrès international d'histoire de l'art Budapest 1969. Évolution générale et développements régionaux en histoire de l'art, 1, Budapest, 1972, 705-713, here 709.

94

CARMEN BERNIS (note 93), 709.

95

A Relation of a Journey (note 70), 30.

96

See: NINA TRAUTH (note 1), 251.

97

Ibid., 252.

98

Außführliche Reisz=Beschreibung / Von Wien nach Constantinopel / und wieder zurück in Teutschland / auch was sich Merchwürdiges dabey zugetragen: Deß hoch=Gebohrnen Grafen und Herrn / Herrn Albrecht Caprara, ec. ec. Welche Er als Ihro Rómisch=Keyserl. Maj. Extraordinari-Gesandter und Gevollmåchtigter / Den Stillstand mit der Ottomannis. Pforten zu verlängern / verrichtet. Beschrieben von Johanne Benaglia, Gesandtschaffts=Secretario. Anjetzo auf vielfaltiges Begehren / auß dem Italianischen / getreulich in die hoch=Teutsche Sprache úbersetzt, Franckfurt, 1687, 7.

99

BOHUMIL DVOŘÁČEK, Nové Město nad Metují. Pohledy do minulosti, Nové Město nad Metují, 2015, 61.

100

PETR LANDR (note 88).

101

PETRA MEDŘÍKOVÁ, Porträtsammlung der Familie Dietrichstein auf Schloss Nikolsburg, in: INGRID HALÁSZOVÁ (ed.), Noblesse im Bild. Die adeligen Porträtgalerien in der Frühen Neuzeit in den Ländern der ehemaligen Habsburgermonarchie (Spectrum Slovakia Series, 13), Frankfurt am Main - Bratislava, 2016, 105-135, here 123.

102

PETRA MEDŘÍKOVÁ (note 101), 123; IGOR WEIGL (note 91), 89.

103

PETRA MEDŘÍKOVÁ (note 101), 134.

104

LUBOMÍR SLAVÍČEK, Inventáře Dietrichsteinské sbírky obrazů (Mikulov, Vídeň). Prameny k dějinám sběratelství 17.-19. století na Moravě, in: Opuscula historiae artium. Studia minora facultatis philosophicae Universitatis Brunensis, F 43 (1999), 67-112, here 99. 105

Státní oblastní archiv v Zámrsku, Roddiny archiv Lesliů, kt. 6, inv. č. 118, Probate inventory of Anna Francisca Countess Leslie, 4 October 1685, fol. 241r-241v.

106

See: POLONA VIDMAR, Turqueries, Orientals and Virtuous Heroes, Ptuj, 2007, 4; FRIEDRICH POLLEROß (note 2), 45-46.
107

On the travel journal see: PHILIP STEINER (note 76); PHILIP STEINER (note 78).

108

Coesarea legatio, quam Mandante Augustissimo Rom: Imperatore Leopoldo I. Ad Portam Ottomanicam suscepit, perfecitque: Excellentissimvs Dominvs, Dominvs Walterus S. R. I. Comes de Leslie, Dominus Pettovij, \& Neostadij ad Mettoviam: Sac: Coec. Majestatis à Consilijs intimis, \& Auloe Bellicis, Campi Marescallus, \& Confiniorum Schlavonioe, \& Petrinice Generalis. Succinctá narratione exposita, Atque Illvstrissimo Domino, Domino Jacobo S. R. I. Comiti de Leslie, Domino Pettovij, \& Neostadij ad Mettoviam: Sac: Coes: Majestatis Camerario, \& Pedestris Reginimis Colonello, Excellentissimi Oratoris Nepoti in perennem Laudatissimi Patrui memoraiam dicato a R. P. P. T. S. J. itineris comite, \& Excellentissimi Oratoris Capellano, Viennæ, 1668.

109

HERBERT HAUPT, Von der Leidenschaft zum Schönen. Fürst Karl Eusebius von Liechtenstein (1611-1684). Quellenband, Wien Köln - Weimar, 1998, notes 842, 858, 926; HAUPT 2006, str. 45.

110

About Frans van der Steen, see ALEX HAJDECKI, Die Niederländer in Wien, in: Oud Holland, 25 (1907), 9-26, here 23; HERBERT HAUPT, Flämische und niederländische Künstler am Wiener Kaiserhof im 17. und 18. Jahrhundert im Überblick, in: Acta historiae artis Slovenica, 11 (2006), 31-46, here 45; FRIEDRICH POLLEROß, "Conterfet Kupfferstich". Neue Erkenntnisse zu den 'Porträtbüchern' des 17. Jahrhunderts, in: Frühneuzeit-Info, 27 (2016), 170-191, here 180, 189.

111

On the portrait, see POLONA VIDMAR (note 106), 4; NINA TRAUTH (note 1), 263; FRIEDRICH POLLEROß (note 2), 50-51.

112

FRIEDRICH POLLEROß (note 2), 51.

113

Devises heroïques, Par M. Claude Paradin, Chanoyne de Beauieu, Lion, 1551, 70; Devises herö̈ques, Par M. Claude Paradin Chanoine de Beaujeu, Lion, 1557, 118-119.

114

Devises heroïques (note 113), 118: "Loliue, ensemble la Masse d'armes, (Deuise de Paix, ou de Guerre) se peut montret aus ennemis, leur ofrant le chois de l'un, ou de l'autre, ainsi que faisoient les Antiques par les Caducee, auec la Lance, mesmes les Rommeins aux Carthaginois (...)."

115

Historia di Leopoldo Cesare (note 73), frontispiece.

116

PHILIP STEINER (note 76), 303; PHILIP STEINER (note 78), 243, 255.

117

Keiserliche Botschafft an die Ottomanische Pforte / welche / auf Befehl ihrer Roem. Keis. Maj. Leopoldus des I. der Hochgebohrne Herr Herr Walter Leslie des H. R. Reichsgraf / Herr zu Pettau und Neustadt ob der Mettau / K. M. geh. und Hof=Krigs=Raht / Feldmarschall/ und über die Windisch= und Sclavonischen Gränzen General, glüklich verrichtet Anfangs in lateinischen Sprache von P. Paul Tafernern / Jesuitern / und Hoch=Gräflichen Reise=Kapellan aus eigener Erfahrung beschrieben / nunmehro aber Dem Teutschliebenden Leser zum besten verteutschet durch B. Z. v. W, 1672.

118

FRIEDRICH POLLEROß (note 2), 65-66.

119

Ibid., 65-66. 
120

PHILIP STEINER (note 76), 280.

121

Der Röm: Kay: May: Leopoldi I. An Deß grossen TürckenSultans (note 80), introductory chapter; see also: IGOR WEIGL (note 91), 88.

122

Der Röm: Kay: May: Leopoldi I. An Deß grossen TürckenSultans (note 80 ).

123

Ps. 121:7 ("Fiat pax in virtute tua et abundantia in turribus tuis"; "Let there be peace in your strength, and abundance in your towers").

124

Der Röm: Kay: May: Leopoldi I. An Deß grossen TürckenSultans (note 80 ), 75 .

125

JOHN. L. NEVINSON (note 15), 92-93.
126

Státní oblastní archiv v Zámrsku, Roddiny archiv Lesliů, kt. 14, inv. č. 317, Inventory of the Austrian properties after the death of James Ernst Count Leslie, 20 December 1737, fol. 10v; see also IGOR WEIGL (note 91), 89.

127

Státní oblastní archiv v Zámrsku, Roddiny archiv Lesliů, kt. 10, inv. č. 211, Willem Aloisius Leslie to Jacob Leslie, 27 May 1684, Nové Město nad Metují, fol. 388r-390v.

128

The research for this article was supported financially by the Slovenian Research Agency as part of the research program Slovenian Artistic Identity in European Context (P6-0061), and the research project Visual Representation of the Nobility: Early Modern Art Patronage in the Styria Province (J6-7410), conducted at the University of Maribor, Faculty of Arts, and the ZRC SAZU, France Stele Institute of Art History, Ljubljana.

Sažetak

\section{Polona Vidmar}

\section{Cæsari in mis omni hora fidelis servivi: Portreti Žigmunda Herbersteina i Waltera Leslieja u diplomatskim odorama}

U članku je riječ o portretima dvojice carskih poslanika otomanskim vladarima - baruna Žigmunda Herbersteina (1486.-1566.), koji se susreo sa sultanom Sulejmanom Veličanstvenim u vojnom logoru blizu Budimpešte 1541., i grofa Waltera Leslieja (1606.-1667.), koji je u poslanstvu kod sultana Mehmeda IV. boravio u Carigradu 1665.-1666. godine. Usprkos osjetnom vremenskom rasponu između njihovih misija, njihovi su portreti odabrani za ovo istraživanje jer, kao što je to već primijetio Friedrich Polleroß, posrijedi nisu samo najstariji, nego ujedno i najdojmljiviji i najvažniji portreti habsburških diplomata u službenim odorama; Arno Strohmeier smatrao je Lesliejevo poslanstvo dobrim primjerom učinkovitog medijskog događaja. Portreti se razmatraju u kontekstu narudžbi, uz osobit naglasak na diplomatskim odorama i samoprezentaciji naručitelja. Herbersteinova odluka da ilustrira svoja autobiografska djela sa šest drvoreznih portreta u cijeloj figuri na kojima je odjeven u diplomatske odore predstavljena je u kontekstu glorificirajućih pjesama tiskanih u nekim prestižnim izdanjima njegovih djela. Premda se ne mogu smatrati nepobitnim dokazom postojanja Herbersteinove galerije portreta, nekoć vjerojatno smještene u njegovoj kući u Beču, dvosmislene poetske reference na slikane portrete stavljene su u širi kontekst onodobnih galerija obiteljskih portreta. Herberstein se tijekom svojih diplomatskih putovanja mogao upoznati s fenomenom galerija portreta nastalih između 1530-ih i 1560-ih godina $\mathrm{u}$ austrijskim i češkim aristokratskim rezidencijama, koje su naručivali dobro obrazovani plemići, ugledajući se na primjere viđene tijekom njihovih posjeta carskim i nadvojvodskim rezidencijama diljem Europe. Pretpostavljena narudžba galerije obiteljskih portreta u skladu je s Herbersteinovim opsežnim genealoškim istraživanjima. U članku se također spominju dva portreta Žigmunda Herbersteina iz 18. stoljeća, koji se danas nalaze u dvorcima Herberstein i Ptuj. Kao predložak za portrete, njihovi su, zasad neznani, naručitelji, oba iz obitelji Herberstein, odabrali drvorez s prikazom Žigmunda u turskom kaftanu.

Izaslanstvo Waltera Leslieja bilo je jedno od sedam velikih carskih poslanstava u Carigradu nakon potpisivanja Žitvanskog mira 1606. godine. Carski dvor za poslanike je odabirao samo važne osobe, a sam Leslie je za svoje zasluge u diplomaciji bio odlikovan redom Zlatnog runa. Za svoj portret pozirao je neznanom, vjerojatno bečkom, slikaru u diplomatskim odorama koje je nosio tijekom ceremonijalnih parada u Beču, Odrinu (Edirne) i Carigradu. U radu se također interpretira i originalni portret sačuvan u Náchodu, u muzeju nedaleko od Lesliejeva dvorca Nové Město nad Metují u sjeveroistočnoj Češkoj (gdje se danas nalazi njegova kopija). Replika portreta, koja se do početka 20. stoljeća spominje u inventarima i popisima slika u dvorcu Mikulov, međutim, nije sačuvana. Portreti Waltera Leslieja ovdje su također sagledani u novome svjetlu na temelju dokumenata iz obiteljskih arhiva. Politička konotacija diplomatskih odora - na što su ukazali pojedini istraživači, ističući da je u skladu s tradicijom habsburških veleposlanika sultanu, Leslie nosio odoru mađarskih velikodostojnika kako bi demonstrirao careve pretenzije prema Mađarskoj - stavljena je ovdje u kontekst todobnih tekstova, u kojima se njegova odjeća definira kao turska. U radu se također razmatraju i bakrorezni portreti Waltera Leslieja koji ilustriraju putopis njegove misije, kao i druge onodobne knjige.

Ključne riječi: Žigmund Herberstein (1486.-1566.), Walter Leslie (1606.-1667.), carski poslanik, portret, Donat Hübschmann, Frans van der Steen 


\section{Izvori ilustracija i autori fotografija / Sources of illustrations and photo Credits}

\begin{abstract}
Višnja Bralić
The Cult of Saint Euphemia, the Patron Saint of Rovinj, and the Venetian Politics of Co-creating Local Identities in Istrian Communities in the $15^{\text {th }}$ Century / Kult sv. Eufemije, zaštitnice Rovinja $i$ venecijanska politika sukreiranja lokalnih identiteta u istarskim zajednicama 15. stoljeća
\end{abstract}

1: (c) Museo Correr, Venezia (Giuseppe Rosaccio, Viaggio da Venezia a Costantinopoli, per mare e per Terra, \& insieme quello di Terra Santa, Venetia: Giacomo Franco, 1598, fol. 7v)

2-10: Ljubo Gamulin

\section{Anna Boreczky}

Historiography and Propaganda in the Royal Court of King Matthias: Hungarian Book Culture at the End of the Middle Ages and Beyond / Historiografija i propaganda na dvoru kralja Matije Korvina. Mađarska kultura knjige krajem srednjega vijeka i dalje

1-11, 14, 16-18: @ National Széchényi Library, Budapest (Országos Széchényi Könyvtár)

12, 13: ( ) Heidelberg University Library (Universitätsbibliothek Heidelberg)

15: From Wikimedia Commons, the free media repository

\section{Ivan Gerát}

Saint George Between Media and Functions / Sv. Juraj izmedu medija i funkija

1: Image courtesy National Gallery of Art, Washington DC

2: https://www.metmuseum.org/art/collection/, Public Domain

3: https://www.metmuseum.org/art/collection/, Public Domain

4, 5: Ivan Gerát

6: Archive of the Institute of Art History of the Slovak Academy of Sciences

\section{Ivan Ferenčak}

The Illustrations in the Glagolitic Books Printed by Bishop Šimun Kožičić Benja in Rijeka (1530-1531) / Ilustracije u glagoljskim knjigama biskupa Šimuna Kožičića Benje tiskanim u Rijeci (1530.-1531.)

1: Tamara Runjak, Rijetkosti u Knjižnici Hrvatske akademije znanosti i umjetnosti: katalog inkunabula i knjiga 16. stoljeća, Zagreb, 2011.

2, 7-10: Zagreb, Knjižnica Hrvatske akademije znanosti i umjetnosti, R-600, snimio Ivan Ferenčak 2019.

3: Ivan Ferenčak, 2019.

4: Biblioteca nazionale Marciana, Venezia, BM - Rari Ven. 579 (su concessione del Ministero per i Beni e le Attività Culturali - Biblioteca Nazionale Marciana. Divieto di riproduzione).

5: Biblioteca nazionale centrale di Firenze, Firenze, MAGL.2.1.109 (su concessione del Ministero dei beni e delle attività culturali. Biblioteca Nazionale Centrale di Firenze. Divieto di riproduzione)
6: Bibliothèque nationale de France, Paris, département Musique, RES-1527.

11: Nacionalna i sveučilišna knjižnica, Zagreb, RIIA- $8^{\circ}-8$.

12: Nacionalna i sveučilišna knjižnica, Zagreb, RIIA-16º-5.

\section{Milan Pelc}

Panegyric Emblem Books, Jesuits and the Habsburg Emperors: Some Examples Related to $17^{\text {th }}$-Century Croatia / Panegirički amblemi $i$ habsburški carevi - primjeri iz 17. stoljeća povezani s hrvatskom kulturnom sredinom

1: ๔ Hrvatski povijesni muzej, Zagreb / Croatian History Museum 2: ( University Library, Budapest / Egyetemi Könyvtár, Kézirattár 3-20: ๑ Austrian National Library, Vienna / Österreichische Nationalbibliothek

\section{Polona Vidmar}

Coesari in mis omni hora fidelis servivi: The Portraits of Sigismund Herberstein and Walter Leslie in Diplomatic Robes / Cæsari in mis omni hora fidelis servivi: Portreti Žigmunda Herbersteina $i$ Waltera Leslieja u diplomatskim odorama

1-2, 4, 6: Knjižnica Ivana Potrča Ptuj / Ivan Potrč Library Ptuj 3: Hollstein's German Engravings, Etchings and Woodcuts 1400-1700, vol. XIII A, 1984

5, 10, 13: Google Books

7-9, 11-12: Polona Vidmar

\section{Nóra G. Etényi}

Broadsheets with Engravings in a Manuscript Chronicle from Ulm: Visual Representations of the Hungarian Kingdom on German Political Leaflets during the War of Reconquest (1683-1699) / Grafički plakati u rukopisnoj kronici iz Ulma: Vizualna reprezentacija Ugarskog Kraljevstva na njemačkim političkim letcima tijekom Velikog turskog rata (1683.-1699.)

1, 4: (C) Austrian National Library Portrait Collection, Vienna / Österreichische Nationalbibliothek Porträtsammlung

2, 3, 6: @ Hungarian National Museum, Budapest / Magyar Nemzeti Múzeum

5, 7: @ National Széchényi Library, Budapest, Apponyi Sammlung / Országos Széchényi Könyvtár, Apponyi Metszet

\section{Werner Telesko}

Graphic prints of the Josephine period (1765/1790) and the propaganda of 'Religious Tolerance' / Grafički listovi Jozefinskog razdoblja (1765./1790.) i propaganda "Vjerske tolerancije"

1: ( ) Austrian National Library, Vienna

2: () Austrian National Library, Vienna

3: ㄷ Vienna Museum 
4: (C) Vienna Museum

5: (C) Vienna Museum

6: C Vienna Museum

\section{Martina Frank}

Representing the Republic in Seventeenth-Century Venice / Predstavljanje Republike u Veneciji 17. stoljeća

1, 3, 4, 5, 12: @ Austrian National Library, Vienna / Österreichische Nationalbibliothek

2, 15: Martina Frank

6: () University Library of Padua / Biblioteca universitaria di Padova

7: @ McNay Art Museum

8: Cat Bauer (https://venetiancat.blogspot.com/2016/11/thanksgiving-in-venice-celebrates-black.html)

9, 10: https://www.lamoneta.it/topic/157941-medaglia-nicol\% C3\%B2-contarini/

11: ๑ José Luiz Bernardes Ribeiro / CC BY-SA 4.0

13: Internet culturale

14: () Marciana National Library / Biblioteca Nazionale Marciana, Venezia

16: ( ) Museo Civico del Castello di San Giusto, Trieste

\section{Bálint Ugry - Maja Žvorc}

The Čakovec Stone Bust Collection: New Identifications, Possible Dating and the Identity of its Commissioner / Zbirka kamenih bisti u Čakovcu: Nove identifikacije, moguće datacije i naručitelj

1, 4, 6, 8, 10: Jovan Kliska

2: ๑ Austrian National Library (Österreichische Nationalbibliothek), Vienna

13, 15: ( ) Museum of Međimurje (Muzej Međimurja), Čakovec

3, 5, 7, 9, 11, 14, 16: Corpus Juris Hungarici, Tyrnaviae, 1751.

12: ( National Széchényi Library (Országos Széchényi Könyvtár), Budapest

17, 18: @ National Archives of Hungary (Magyar Nemzeti Levéltár), Budapest

19: Bálint Ugry

\section{Damir Tulić}

Glory Crowned in Marble: Self-promotion of Individuals and Families in Seventeenth- and Eighteenth-Century Monuments in Istria and Dalmatia / Slava okrunjena mramorom: Samopromocija osoba $i$ obitelji na spomenicima 17. i 18. stoljeća u Istri i Dalmaciji

1, 2, 3, 4, 5, 6, 7, 8, 9, 10, 11, 12, 13, 15, 16, 17: Damir Tulić

14: Samo Štefanac

\section{Jasminka Najcer Sabljak}

Portraits of Habsburg Rulers in the Aristocratic Collections of Eastern Croatia / Portreti vladara obitelji Habsburg u plemićkim zbirkama istočne Hrvatske

\author{
1, 2: ( $)$ Galerija Matice srpske, Novi Sad \\ 3: Francisca Clary-Aldringen \\ 4: Davor Šarić
}

\section{Danko Zelić}

Projekt Fausta Vrančića za opsadu Ostendea iz 1603. godine / Faust Vrančićs Design for the Siege of Ostend from the Year 1603

1: Matthias Dögen, Architectura militaris moderna (...), Amstelodami, 1647., 354-355.
2-4: ( ) Rijksarchief in België / Archives de l'État en Belgique, Algemeen Rijksarchief / Archives générales du Royaume, Fond Duitse Staatssecretarie / Secrétairerie d'État Allemande, 413, p. 309

5: Pompeo Giustiniano, Delle guerre di Fiandra libri 6. Di Pompeo Giustiniano del Consiglio di guerra di S. M. C. (...) Posti in luce da Gioseppe Gamurini (...) con le figure delle cose più notabili, In Anversa, 1609., 84-85

\section{Radoslav Tomić}

Generalni providur Leonardo Foscolo i umjetnost u Dalmaciji / Provveditore generale Leonardo Foscolo and Art in Dalmatia

1-30: Fotografije iz arhive autora

4: Presnimak iz: Alfons Pavich pl. Pfauenthal, Prinosi povijesti Poljica, Sarajevo, 1903., 79.

\section{Petar Puhmajer}

Dvorac Cernik - kontinuitet i mijene predturskog nasljeđa u barokno doba / The Cernik Castle - Continuity and Change in the Pre-Ottoman Heritage during the Baroque Era

1, 2, 9: Paolo Mofardin, Fototeka IPU

3 a, b; 6 a , b c c, d: arhitektonski snimak Sanja Štok i Barbara Kulmer, grafička obrada Marin Čalušić

4, 7, 10, 11: Petar Puhmajer

5: ๑ Generallandesarchiv, Karlsruhe

\section{Bojan Goja}

Kuća Cattinelli 1772. godine: prilog poznavanju stambene arhitekture u Zadru u 18. stoljeću /

The Cattinelli House in 1772: A Contribution to Our Knowledge of Housing Architecture in $18^{\text {th }}$-Century Zadar

1, 2: Bojan Goja

3, 4: Branko Maroević, dipl. ing. arh., izrada nacrta

\section{Iva Pasini Tržec}

Slike starih majstora iz zbirke Ervina i Branke Weiss u Strossmayerovoj galeriji u Zagrebu / Paintings of Old Masters from the Collection of Ervin and Branka Weiss in the Strossmayer Gallery in Zagreb

1, 3, 6: Arhiv Strossmayerove galerije HAZU, dokumentacija Weiss 2: MAK - Museum of Applied Arts (Museum für angewandte Kunst), Vienna

4: RKD - Netherlands Institute for Art History (Rijksbureau voor Kunsthistorische Documentatie), Den Haag

5: Palais Liechtenstein, Vienna

6: ( ) Strossmayerova galerija starih majstora HAZU

7: BDA - Bundesdenkmalamt Archiv (Federal Monuments Authority Austria Archive), Vienna

\section{Irena Kraševac}

Prva tri djela u fundusu Moderne galerije Društva umjetnosti / The First Three Artworks in the Holdings of the Modern Gallery of the Art Society in Zagreb

1, 4: Goran Vranić, Moderna galerija, Zagreb

2: Paolo Mofardin, Institut za povijest umjetnosti, Zagreb

3: digitalna presnimka iz kataloga izložbe: Ivan Meštrović. Skulpturen, Nationalgalerie, Staatliche Museen Preußischer Kulturbesitz, Berlin, 1987. (Nenad Gattin?)

5: Arhiv Galerije grada Praga / Archive of Prague City Gallery 